Review Paper

\title{
Clay nano-adsorbent: structures, applications and mechanism for water treatment
}

\author{
Anuradha Awasthi ${ }^{1,2} \cdot$ Pradip Jadhao $^{1,2} \cdot$ Kanchan Kumari $^{1,2}$ (D)
}

(c) Springer Nature Switzerland AG 2019

\begin{abstract}
Nanotechnology plays an important role in current environmental practices for remediation of contaminants in environment. From last few years, nano-clay has found more attention because of its unique characteristics and properties. Clay and clay minerals are very important naturally occurring mineral playing key role in environmental protection. Clay basically originates from raw minerals, having different types of geometry and morphology. These clay minerals have been used in disposal and storage of hazardous chemicals as well as for remediation of contaminated water. In several industries, clay minerals have been used as raw materials for hundreds of industrial applications due to its abundant availability and inexpensive nature. Because of unique properties and high removal efficiency, clay is used as nano-adsorbent in many adsorption processes. Nano-clays act as a promising property enhancer found highly effective and efficient for water purification. The use of clay minerals as adsorbents for adsorption of various hazardous substances like-heavy metals, dyes, antibiotics, biocide compounds, and other organic chemicals has been widely studied by a large number of researchers. In the present review paper, authors highlights the nano-composites and their preparation methods, adsorption mechanism and has compiled the past and current research works carried out by different researchers on innovation in nanoclay, upcoming advancement, and/or mechanism for removal of contaminants by different nanoclays for water purification.
\end{abstract}

Keywords Adsorption $\cdot$ Water treatment $\cdot$ Nanoclay adsorbent $\cdot$ Nanotechnology $\cdot$ Nanocomposites

\section{Introduction}

\subsection{Environmental nanotechnology}

Environmental degradation as a result of development of advanced technologies is one of the serious global concerns [42]. Wastewater from different industrial process are one of the major sources of contamination in natural water bodies [17]. Fresh drinking water is a basic need of a healthy human community. The discharge of hazardous materials into the water bodies is growing substantially. However, increased use of toxic substances for different concerns has significantly raised the load of unwanted pollutants in clean water across the world [17]. The contamination of drinking water with heavy metals like arsenic, fluoride etc. and high load of dissolved solids are of major concern. On the other hand, microbial pathogens are major cause of water borne diseases among children [26]. It is merely not possible to remove these harmful contaminants from water. The safest approach to solve this global problem is to develop cost effective and efficient water treatment technologies, which needs a nonpolluting \& eco-friendly materials and process that too in a cost-effective manner.

Nanotechnology comprises the manufacturing along with management of materials at the nano level scale, either by scaling up from single groups of atoms or by refining or reducing bulk materials [76]. In the present

$\triangle$ Kanchan Kumari, onlinekanchan1@gmail.com | ${ }^{1}$ Environmental Impact and Sustainability Division, CSIR-National Environmental Engineering Research Institute, Nagpur, India. ${ }^{2}$ Academy of Scientific and Innovative Research (AcSIR), Ghaziabad 201002, India. 
scenario, nanotechnology has been used in different applications of science and technology such as sectors dealing with energy [67], industrial processes, sensors [129] and more broadly for environmental applications [90, 91]. Nanotechnology based approaches have developed efficient methods and materials for the solution of many challenging problems which were not solved with the help of previous technologies and conventional methods. It requires a combination of nanomaterials, nanocomposites and natural materials for a beneficial and successful treatment method for decontamination of water [113]. From past several years, different nano-based technologies were used for treatment of waste water and management of its sources. Nano structured materials are the principle component of nanotechnology.

\subsection{Nanomaterials}

Nanomaterials are structural and functional units of nanotechnology. Nanostructure science is extensive and interdisciplinary research area that has been rising exponentially worldwide in the last few decades [64]. It has the potential for transforming the pathways in which materials and products are developed and variety and behavior of functionalities can be retrieved. It is already having a momentous marketable impact, which will undoubtedly rise in the near future. Advantages of the nanomaterials in the field of water treatment and purification have been discussed in the next (1.3) paragraph.

\subsection{Advantages of nanomaterial in water treatment}

Nanotechnology is an emerging field and covers a wide range of technologies which are presently under the process of development at nanoscale [114]. It plays a major role in the development of innovative methods to produce new products, to substitute existing production equipment and to reformulate new materials and chemicals with improved performance resulting in less consumption of energy and materials and reducing environmental degradations well as enhancing the rate of environmental remediation [45]. New approaches are continually being examined to supplement traditional water treatment methods. These needs to be lower in cost and more effective than current available techniques for the removal of contaminants from water, in this context also nano-technological approaches are considered [74]. Nanoparticles used as potent adsorbents, in some cases are combined with magnetic particles to ease particle separation; nanoparticles used as catalysts for chemical or photochemical destruction of contaminants; nanosized zero-valent iron used for the removal of metals and organic compounds from water; and nano-filtration membranes [12].
Nanoparticles have a great potential to be used in waste water treatment. Its unique characteristic of having high surface area can be used efficiently in removal of toxic metal ions, disease causing microbes, organic and inorganic solutes from water [79]. Various classes of nanomaterials are also proved to be efficient for water treatment like metal-containing nanoparticles, carbonaceous nanomaterials, zeolites and dendrimers. This paper reviews recent advances on nano clay materials as an adsorbent with their application and mechanism in water treatment and purification. Another major field of nanomaterial is nanocomposites, that have high efficiency for removal of contaminants from water $[90,91]$.

\section{Nanocomposite}

In nanocomposites, one of the phases are in nanometer range $\left(1 \mathrm{~nm}=10^{-9} \mathrm{~m}\right)$ and they differ from conventional composite with microscale structure, due to their small size and the increment in surface-to-volume ratio [10, 39, 59].

Nanocomposites have been defined by various scientist as:

- Nanocomposites are "Products with the nanoscale properties that improves the macroscopic quality of the material" [9].

- Nanocomposite as a solid multiphase material, where one of the phases is 1,2 and 3-dimensional property with nanometer range $(100 \mathrm{~nm})$ having electrical, thermal, optical, mechanical, electrochemical and catalytic qualities and will vary distinctly from the component materials [52].

The definition of nano-composite materials has over the years extended significantly to include different varieties of a system like- amorphous and 1,2 and 3-dimensional materials, synthesized by two dissimilar materials at the nanometer scale. Thus, the nanocomposite material is a modified advance material having the property of ( 1 billion of a meter) fillers isolated from variety of different matrix. The stage may be the same as inorganic-inorganic, organic-organic or may be different combination like organic-inorganic [71]. The organic/inorganic class of combination of materials is a potential area of new and advanced research can be taken up.

\subsection{Classification of nano-composite}

Nanocomposites can be categorized, according to their structural and matrix differences, in three different classes as shown in Fig. 1. 


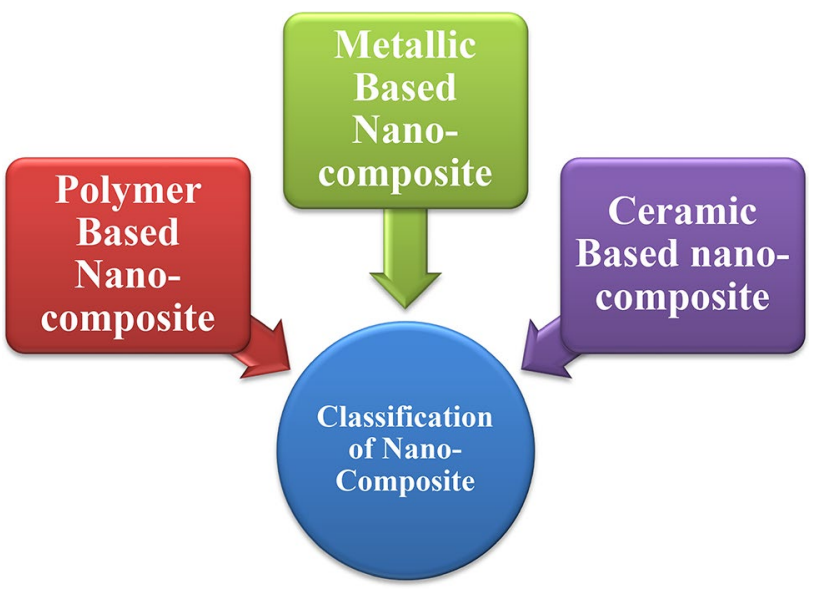

Fig. 1 Classification of nano-composites

\subsubsection{Metal based nano-composite}

Consists of metallic nanomaterials such as $\mathrm{Fe}-\mathrm{Cr} / \mathrm{Al}_{2} \mathrm{O}_{3}$, $\mathrm{Ni} / \mathrm{Al}_{2} \mathrm{O}_{3}, \mathrm{CO} / \mathrm{Cr}, \mathrm{Fe} / \mathrm{MgO}, \mathrm{Al} / \mathrm{CNT}$ and $\mathrm{Mg} / \mathrm{CNT}$ etc. with improved magnetic properties like- Superparamagnetism, saturation magnetization also having the property of high electrical resistivity by the disordered grain surface. They have major application in aerospace and automotive industries for the synthesis of structural materials [3]. Metal composites along with ceramic composites with CNT showed better results in environmental applications [116].

\subsubsection{Polymer-based nano-composite (PBNC)}

Consists of thermoplastics, thermoset, layered polymers, modified polymer titanium dioxide, carbon nano tubes with polymer hydroxides with a double layered polymers. Polymer based nanocomposites are extensively used in several industry due to their unique properties such as: easy manufacturing process, ductile nature and light weight. Except this, PBNC have low strength and this is the major disadvantage in comparison to ceramic based nanocomposite and metal nanocomposite. The most effective approach to improve mechanical properties of polymer based nano-composites is the combination of some materials like-addition of fibers, whiskers, particles to supports the polymer matrix for its longer stability [51].

These nanocomposites are of two types:

(a) Thermoplastic nanocomposites: These materials are divided into two broad categories: Product generation and Engineering. Thermoplastics filled with nanomaterials have several added features compared with the thermoplastics having conventional materials. (b) Thermoset nanocomposites: These composites are not much significant but it can be manufactured using simple methods.

The following other filler materials are used for the synthesis of nanocomposites.

- Organo montmorillonite

- Carbon nanofibres

- Carbon nanotubes

- Metallic nanomaterials

- Ceramics, etc.

\subsubsection{Ceramic-based nano-composite (CBNC)}

$\mathrm{Al}_{2} \mathrm{O}_{3} / \mathrm{SiO}_{2}, \mathrm{Al}_{2} \mathrm{O}_{3} / \mathrm{TiO}_{2}$, and $\mathrm{SiO}_{2} / \mathrm{Ni}$ etc. are the ceramicbased nano-composites. Some experimental studies showed that the toughening mechanism of CBNC is based on the crack-bridging role of the nano sized reinforcements [133]. Therefore, addition of such high strength nanofibres into ceramic matrices has permits the manufacturing of innovative nanocomposites with high toughness and endurance [54].

\subsubsection{Nanocomposites: methods and preparation}

Ceramic matrix nanocomposites can be prepared by several methods. The most common methods are (1) Power method of conventional technique such as: Spray pyrolysis, precursor route and vapor deposition technique (2) Chemical synthesis methods like-sol-gel, precipitation and colloidal techniques. The methods for preparation of metal matrix nanocomposites are: Liquid metal infiltration, Vapor and Electro-deposition methods and spray pyrolysis. The most important of themincludes reversible inclusion of polymer or pre-polymer in the matrix; In-situ insertion of molecule in polymerization; a straight combination of polymer and substances present; synthesis of template; In-situ polymerization along with sol-gel process [15].

As discussed in the above literature, different types of nanocomposites materials have proved their efficiency as good nano-adsorbent for removal of contaminants from the water. Different types of clay nanocomposites have also been successfully used as a nanoadsorbent for different sector of environment for treatment and water purification processes.

\section{Nanomaterial as a nano-absorbent}

Nowadays a number of technologies have been introduced into the market for the treatment of water and these advance technologies are gaining attention for 
the removal of metallic pollutants from waste water; reverse osmosis and membrane filtration are some of the popular technologies being used however coagulation, flocculation and electrolytic removal are also being used in several industries [82, 135]. But these commercial water treatment units are available in the market with variable affordable prices have various disadvantages e.g. consumption of non-renewable energy (being paid in terms of electricity bills), replacement of cartridge (extra burden on the budget) and one of the most important factors is removal of essential minerals like-Ca and $\mathrm{Mg}$ which is vital for the human body. So, these commercial units that looks affordable in the first instance to the customers are actually more costly when taken into account. Therefore, there is a requirement of low-priced treatment technology and materials for the removal of such types of contaminants is need of the hour and nano adsorbents have emerged as a fascinating field of research for the removal of these hazardous pollutants from the water $[6,7]$.

\subsection{Nano sorbents}

Nano sorbents are the functional units of nanoscience for the adsorption of organic and inorganic substances. Nano adsorbent contains a high capacity to remove the contaminants by adsorption [109]. Figure 2 highlights different types of nano adsorbents used for remediation of contaminants. Nanoadsorbent have been proven having a huge potential for the remediation of pollutants from air and waste water [65]. Nanoadsorbent offers a field of great sorption materials for environmental applications [98]. Use of adsorbents for removal of metallic contaminants in industrial effluents and water should fulfill the following conditions:

1. Nano sorbents should be nontoxic in nature.

2. The sorbents should have high potential of sorption even with low concentration of contaminants.

3. Surface removal of adsorbed contaminant should be easy to remove and

4. The adsorbent could be recycled and regenerated easily.

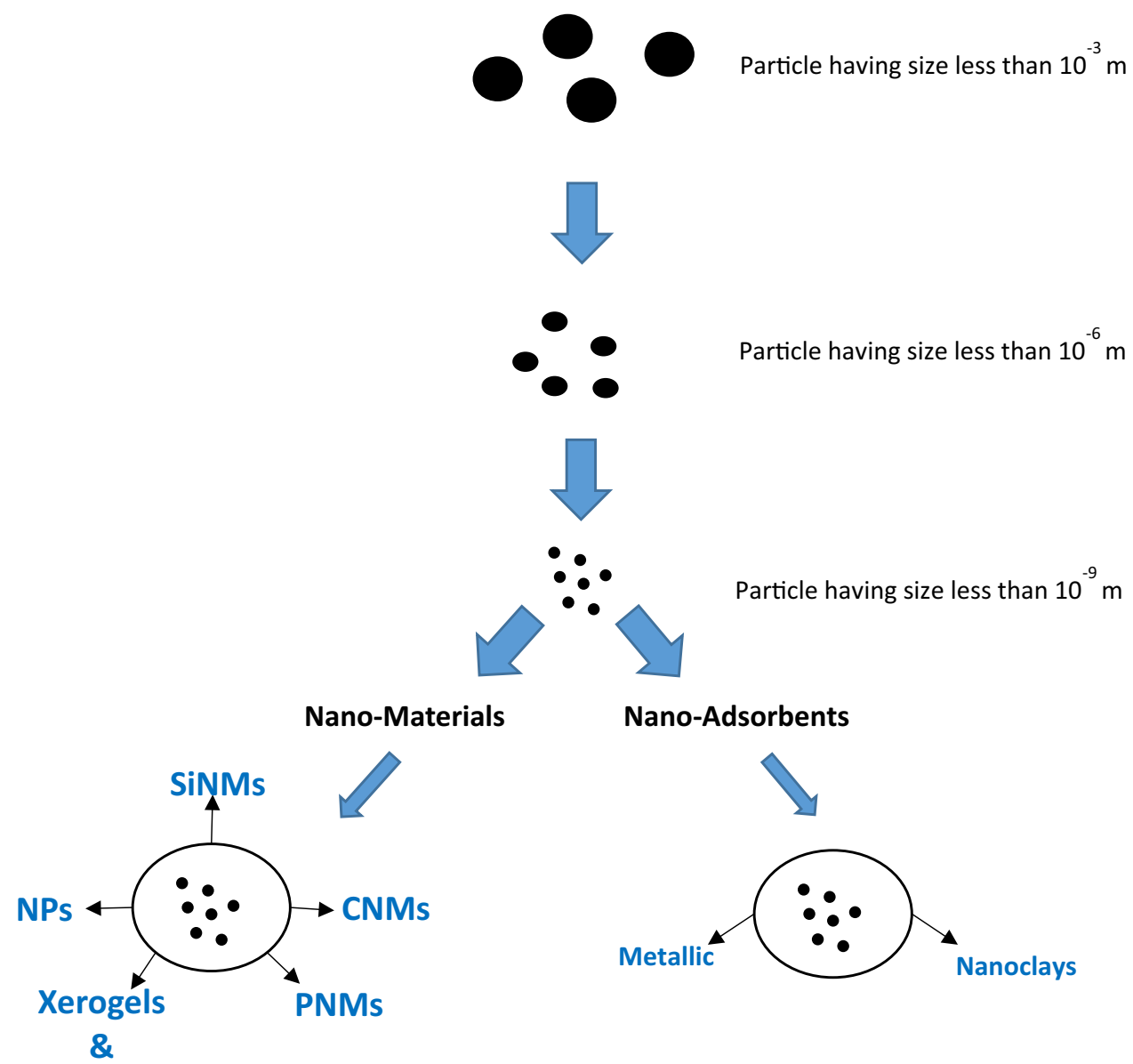

Fig. 2 Types of nano-materials

Aerogels 
Section 2 of review paper explained the phenomenon of adsorption its process and kinetics for the removal of contaminants from the water.

\section{Adsorption}

Adsorption is a process of removal of soluble materials present in water and in this process, solid adsorbents are being used for the adsorption of contaminants. The most popular solid adsorbent material is activated carbon, which is used in large scale industries for domestic level water purification systems because of its high internal surface area $\left(500-1500 \mathrm{~m}^{2} / \mathrm{g}\right)$. High surface area of this adsorbent shows the high affinity of adsorption. The adsorption of substances from water basically depends upon two types of mechanism: Hydrophobic and hydrophilic; the solubility of material in water is very important, the terms solubility represents the chemical interaction or activity of solute and water. It means the high hydrophilic substance lowers the adsorption and vice versa. The main factor which works behind this mechanism is driving force that decreases the surface tension between the matrix and the solid adsorbed $[35,50,100,102]$.

\subsection{Adsorption isotherm}

The adsorption is the phenomenon in which the amount of adsorbate is adsorbed on the surface of material, at constant temperature and fixed pressure. There are several types of adsorption mechanism, out of which Langmuir and Freundlich adsorption isotherm is most widely used and accepted. The classification of different types of adsorption isotherm is represented in Fig. 3.

The mechanism of adsorption isotherm has been explained below.

\subsubsection{Langmuir adsorption isotherm}

Langmuir [60], explained the concept of adsorption isotherm on theoretical basis for the kinetic theory of gases. Langmuir adsorption is based on monolayer adsorption on the homogeneous surface; this model also suggests that there is no lateral interaction between sorbet molecules [37]. The Eqs. (1) and (2) express the linear and non-linear model of adsorption isotherm.

$\frac{1}{q_{e}}=\frac{1}{Q_{0}}+\frac{1}{b Q_{0} C_{e}}$

$$
q_{e}=\frac{Q_{0} b C_{e}}{1+b C_{e}}
$$

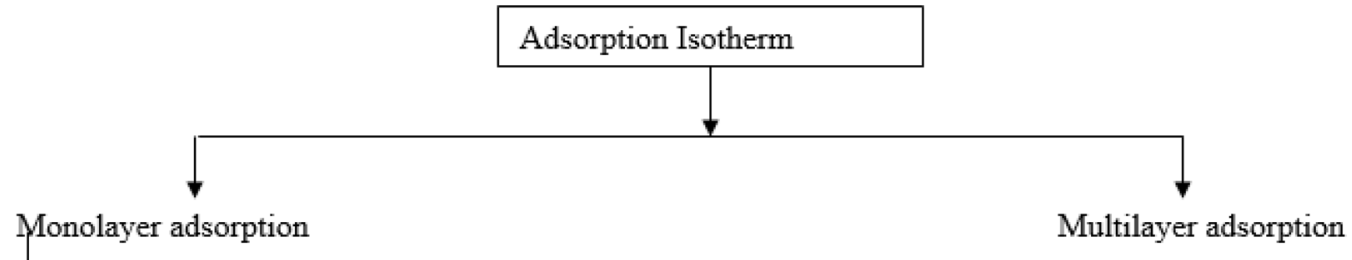

e.g. Langmuir Adsorption Isotherm Linear equation

$$
\frac{1}{q_{e}}=\frac{1}{Q_{0}}+\frac{1}{b Q_{0} C_{e}}
$$

Non-Linear equation

$$
q_{e}=\frac{Q_{0} b C_{e}}{1+b C_{e}}
$$

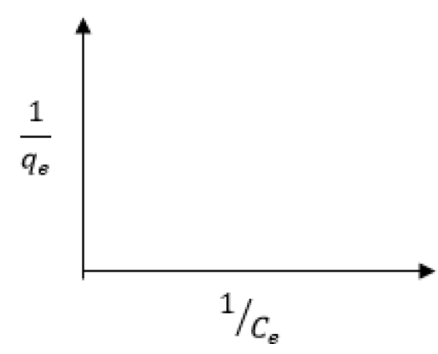

Fig. 3 Classification of adsorption isotherm e.g. Freundlich Adsorption Isotherm Linear equation

Non-linear equation

$$
\ln \left(q_{e}\right)=\ln K_{f}+(1 / n) \ln C_{e}
$$

$$
q_{e}=K_{f} C_{e}^{1 / n}
$$

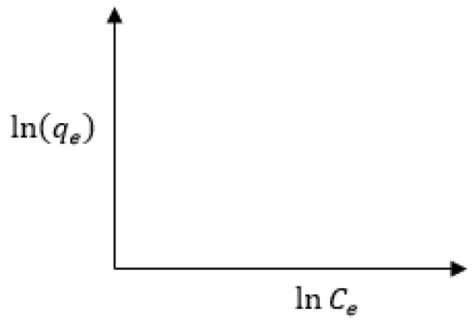


where $\mathrm{q}_{\mathrm{e}}$ is amount of adsorbate adsorbed, $\mathrm{Q}_{0}$ maximum capacity of the monolayer for adsorption, the $b$ constant of Langmuir adsorption isotherm model, $C_{e}$ is concentration of equilibrium where two processes when some of the gas molecules strike on the solid surface and some are evaporated or desorbed [61].

\subsubsection{Adsorption isotherm theory of Freundlich}

Freundlich adsorption theory explained the mechanism of multilayer adsorption of adsorbate on the surface of adsorbent. It indicates the heterogeneity on the surface of adsorbate. The Eqs. (3) and (4) express the linear and non-linear model of adsorption isotherm [37, 38].

$\ln \left(q_{e}\right)=\ln K_{f}+(1 / n) \ln C_{e}$

$q_{e}=K_{f} C_{e}^{1 / n}$

where $\mathrm{q}_{\mathrm{e}}$ is amount of adsorbate adsorbed, $n$ is intensity of adsorption, $\mathrm{K}_{\mathrm{f}}$ is constant of Freundlich adsorption isotherm model which is related to adsorption capacity, $C_{e}$ is concentration of equilibrium.

\subsubsection{Adsorption kinetics}

To determine the kinetics of the adsorption process, there are several models determining the adsorption kinetics. Some of them are discussed in this paper.

4.1.3.1 Elovich equation Elovich model is generally used for the chemical adsorption processes having heterogeneous surface adsorption. This model applies when, surface coverage rate depends upon the time for the chemical adsorption on the solid surface where gas molecule adsorbed without desorption of the products. At that condition the Elovich Eq. (5) express as:

$\frac{d q_{t}}{d t}=a \exp \left(-b q_{t}\right)$

where $a$ and $b$ are the adsorption rate at the initial stage and constant of Elovich equation, $q_{\mathrm{t}}$ is the amount of adsorption [130].

4.1.3.2 Pseudo-first-order equation of Lagergren's Lagergren's [58] investigated the simple kinetic model explained the sorption process in solid/liquid by pseudo-first-order expression, that is

$\frac{d q_{t}}{d t}=k_{1}\left(q_{e}-q_{t}\right)$

where $k_{1}$ is represents the rate constant of pseudo-first order reaction for adsorption processes, $\mathrm{q}_{\mathrm{e}}$ and $q_{\mathrm{t}}$ denotes volume of adsorbate adsorbed at the time $t$ at equilibrium condition (4).

4.1.3.3 Second kinetic model of Pseudo reaction This model used for envisaging the kinetic parameters, also, it is based on the hypothesis where sorption takes place by the second order chemical adsorption, the linear expression given as follows

$\begin{aligned} \frac{t}{q_{t}} & =\frac{1}{h}+\frac{t}{q_{e}} \\ h & =K q_{e}^{2}\end{aligned}$

where $q_{\mathrm{t}}$ is volume of adsorbent adsorb on adsorbate in time $t, h$ is the primary sorption rate and $\mathrm{q}_{\mathrm{e}}$ is the volume of adsorbent adsorbed at equilibrium [44].

4.1.3.4 Weber and Morris model The model also called as intra particle diffusion model which is used for the determination of the rate of adsorption in the liquid system because of internal diffusion (6). The general equation expresses as follows

$q=K_{\text {in }} t^{n}+C$

The equation gives time progress of the concentration in the state of adsorption. Where $K_{\text {in }}$ is the rate constant [117].

A study carried by Jagtap et al. [44], while demonstrating the experiment in which chitosan was used for defluoridation of fluoride from the drinking water used Langmuir adsorption isotherm to understand the phenomenon of adsorption of fluoride on chitosan surface and plotted the graph $1 / q_{e}$ against $1 / C_{e}$. The removal efficiency was calculated by following expression in which they found the dimensionless quantity $(r)$ as 0.62 (if the $r$ value $r<1$ adsorption favorable if $r>1$ adsorption unfavorable) and therefore, he concluded that the adsorption was favorable in the demonstrated experiments.

$r=\frac{1}{1+b C_{0}}$

Langmuir and Freundlich both adsorption isotherm was studied for adsorption study was found the value of Correlation factor $\left(R^{2}\right)$ of Langmuir theory $\left(R^{2}=0.977\right)$ was reported higher value of Freundlich [27] adsorption isotherm $\left(R^{2}=0.964\right)$ which concluded adsorption of fluoride by monolayer in uniform surface. In another study [126] has been stated that the both Langmuir and Freundlich adsorption isotherm also the help to understand for removing the concentration of heavy metal from wastewater with the help of nanomaterial is a solid surface. 
Section 3 explained the nanoclay mineral, its structure with property, mechanism and application for the water treatment.

\section{Nano-clay mineral}

Nano clay originates from naturally occurring clays, which are mainly made up of finely divided mineral particles. The major portion of clay minerals is covered by layered silicates, which are made-up of silicon and oxygen bonds with some other elements. They can be thought of as a "stack" of two-dimensional single, double or multilayers, which are formed by corner-linked silicate $\left(\mathrm{SiO}_{4}\right)$ tetrahedrons [49]. Due to the absence of chemical bond between layers of the clay geometry, the capacity of stacks layers increases leading for better absorption and dissipation of water and other available molecules. Such minerals affect the swelling or shrinking properties of the clay.

Clays have been unique in structure and chief commercial mineral, which is used in the industries; and gaining high attention in the current scope of nanotechnology [132]. Multiple application of clay minerals has been reported in the several branches of the science and technology. This enhances the efficiency and improves the quality of the products and also cut down the cost that ultimately protecting the environment. Nano-clays are abundantly present in nature and are related to major group of clay minerals. Clay mineral is an old material used by several ceramists from the prehistoric period to present for making of different types of clay products. China used Kaolin clay (China clay) from the third century for production of several products [89]. Basically, Single layer consists of 2, 3 and 4 layers of silica tetrahedra or aluminum hydroxide octahedra. Cays are made up of hydrous silicates having sharp and fine particles arranged in sheet-like manner. Sheet-like structure of clay minerals are called sheet-structure silicates and Phyllosilicates [72, 134]. Geometry of theses silicates is arranged as pages of a book like manner on one and another with same gaps of Van der Waals forces present between each layers, which is named as 'interlayer". Each interlayer made up of substitutions of ion in the layers or sheet of clay minerals and contains negative charges on the surface, this negative charge neutralized by the cations present in the inter-lamellar spaces in the structure of clay. These cations are called exchangeable cations because they can be easily substituted by some new molecules and anions for the modifications of the surface chemistry for desired use of clay mineral. Some major cations present in the inter-lamella spaces are sodium $\left(\mathrm{Na}^{+}\right)$, potassium $\left(\mathrm{K}^{+}\right)$, magnesium $\left(\mathrm{Mg}^{2+}\right)$, and calcium $\left(\mathrm{Ca}^{2+}\right)$, which are available as exchangeable cations and replaced by surface modifications. In general, material efficiency is based on the chemical structure and performance of the material but in case of clay, its physical characteristics plays a key role to define the different groups of clay [81]. Several separation methods are being used for the processing and extraction process of clay minerals like- centrifugation (energetic stirring), freeze-drying and ultra-centrifugation.

\subsection{Classification and properties of clay}

Clay minerals have a different type of physical properties like- shrinkage and air-drying in the presence of fire, plasticity, hardness, porosity and adsorption ability [18]. Clay minerals having very small molecular size and high porous property with the large surface area created the good physical and chemical reactions on the surface of clay minerals. These reactions occurred on the surface of clay with favorable conditions such as high electrostatic revulsion, specific cation exchange with crystallinity owing the process of adsorption. The effective porous surface of nano-clay develops higher bonding power on the surface with containment. Hydrous aluminosilicates structure of clay consists of metal and minerals oxides with wider property of stability. These qualities of clay minerals classified clay in some groups but the major class of clay is Kaolinite, montmorillonite, and illite and associated groups according to the Grim's Classification [31]. These types of clay minerals have different types of structural units.

\subsubsection{Structures of nano-clays}

The characteristics that decide the configuration of a mineral have come from its chemical structure, geometrical arrangements of molecules and ions, with the electrical forces that bind the molecules in the structure [40]. The eight main elements such as $\mathrm{O}_{2+}, \mathrm{Si}^{4+}, \mathrm{Al}^{3+}, \mathrm{Fe}^{2+} \mathrm{Mg}^{2+} \mathrm{Ca}^{2+}$, $\mathrm{Na}^{2+}$, and $\mathrm{K}^{+}$are the major constituent of the $99 \%$ of the earth crust. The majority of clay minerals consist of $\mathrm{Si}$ and $\left(\mathrm{Al}_{2} \mathrm{O}_{3}\right)$ sheets that directly belongs to the Phyllosilicates family [63]. The sub classification of these two major families totally depends on the layer structure. The interconnected sheets of silicates attached with the other sheets of metallic oxygen and with hydroxyl ions [32]. The basic ratio of clay mineral is 1:1 in which one portion is tetrahedral sheet and other is octahedral sheet [128]. In the structure of octahedrons consist of 2 planes of $\mathrm{OH}^{-}$which lies a plan of $\mathrm{Mg}$ and $\mathrm{Al}$ ions, which usually synchronized by hydroxyl sheets with octahedral geometry. The arrangement of these octahedrons in a hexagonal pattern called octahedral sheets [80]. This 2:1 ratio for clay minerals consists of smectite along with mica are major group present in clay mineral family. 


\section{Description of some of the major clay minerals with its structural properties and applications}

The major composition of clay mineral is the same usually consist of two major geometry, one is the tetrahedral and second is octahedral sheets, arranged collectively in different structure. Difference in actual structure of the clay minerals developed the new kind of clay minerals. Some of the major group of clay minerals are discussed below.

\subsection{Kaolin}

Kaolinite group is a basic and broad group having the different clay minerals such as: dickite, nacrite, kaolinite and halloysite; developed by decomposition process of (orthoclase) feldspar. The dickite and nacrite clays are hydrothermally originated with the mixture of kaolinite [84]. Major composition of kaolinite group is silica (tetrahedrons) and alumina (octahedrons). The arrangement of silica tetrahedrons and alumina octahedrons is 1:1 layered stacking, because of which kaolinite is also called 1:1 clay mineral. The schematic structure of kaolinite is shown in Fig. 4. Kaolin clay is having several industrial applications, it is one of the chief clay minerals in the kaolinite group and also called the china clay. Kaolin use as a filler in the paper and plastic industries for coating and paper filler and its unique size and shape makes it suitable for different application. Its chemically inert structure and fine particle size with white color makes kaolin as best product for the ceramic raw materials, catalyst and adhesives and as an adsorbent for water treatment. The structural formula of kaolinite group is $\mathrm{Al}_{2} \mathrm{Si}_{2} \mathrm{O}_{5}(\mathrm{OH})_{4}$ and major portion is covered by $\mathrm{SiO}_{2}, \mathrm{Al}_{2} \mathrm{O}_{3}, \mathrm{H}_{2} \mathrm{O}$ and minor portion is $\mathrm{Mg}, \mathrm{K}$, $\mathrm{Fe}$, Ti, etc. elements.

\subsection{Smectite and montmorillonite}

Smectite is the largest and key class of phyllosilicates clay mineral group. Smectite is chemically very different from the kaolinite group minerals. The symmetry of smectite clay mineral is equidimensional and elongate. Elongate structure of smectite having iron montmorillonite (nontronite) and magnesium montmorillonite (saponite) and lithium montmorillonite (hectorite). The special property of smectite group is replacement of octahedral and tetrahedral sheets. Substitution of $\mathrm{Mg}$ and $\mathrm{Fe}$ in the place of aluminum in octahedral sheet and replacement of alumina and silicates in the tetrahedral sheet [84]. Ca and $\mathrm{Na}$ montmorillonite are major mineral of clay in the group of smectite having minor geometrical dissimilarities in the geometry. Na montmorillonite have a one layer of water while Ca montmorillonite have two water layer in interlayer location in the structure. Na-montmorillonite possesses high swelling capacity and viscosity as compared with the Ca- montmorillonite due to the presence of two water layer in the internal position. Different structural geometry makes smectite group mineral more convenient for the application in the different fields of environment such as good adsorbent (industrial adsorbent), organoclay (nano-clay) for water treatment, food additives, desiccants, emulsion etc. The common structural formula of the this group is $(\mathrm{Ca}, \mathrm{Na}, \mathrm{H})(\mathrm{Al}, \mathrm{Mg}, \mathrm{Fe}, \mathrm{Zn})_{2}(\mathrm{Si}, \mathrm{Al})_{4} \mathrm{O}_{10}(\mathrm{OH})_{2}-\mathrm{XH} 2 \mathrm{O}$.

\subsection{Chlorite}

Chlorite group represents the tetrahedral:octaherdr al:tetrahedral (2:1) layers with the molecular formula $(\mathrm{Mg}, \mathrm{Fe}, \mathrm{Li})_{6} \mathrm{AlSi}_{3} \mathrm{O}_{10}(\mathrm{OH})_{8}$. Single group member also have their individual chemical structure like chamosite $\left(\mathrm{Fe}^{2+} \mathrm{Mg}\right)_{5} \mathrm{Al}\left(\mathrm{AlSi}_{3} \mathrm{O}_{10}\right)(\mathrm{OH})_{8}$, cookeite $\mathrm{LiAl}_{5} \mathrm{Si}_{3} \mathrm{O} 10(\mathrm{OH})_{8 \prime}$ orthochamosite $\left(\mathrm{Fe}^{2+} \mathrm{Mg}, \mathrm{Fe}^{3+} 5 \mathrm{AI}(\mathrm{AlSi} 3 \mathrm{O} 10)(\mathrm{OH}, \mathrm{O})_{8}{ }\right.$, Clinochlore $\left(\mathrm{Mg}, \mathrm{Fe}^{2+} 5 \mathrm{Al}_{2} \mathrm{Si}_{3} \mathrm{O} 10(\mathrm{OH})_{8}\right.$. High presence of chlorite is found in shals. This group includes variety of clay such as: clinochlore, cookeite, donbassite, franklinfurnaceite, nimite, orthochamosite, sudoite, baileychlore and borocookeite [43]. Extensive range of applications of Palygorskite and sepiolitein the industrial sector are also reported [43]. 2:1 layer Palygorskite and sepiolite silicates contains a 2-dimensional tetrahedral sheet and octahedral sheets in 1-dimension. The tetrahedral sheets are grouped into ribbons like structure, every ribbon joints with the following adjacent ribbon with overturn of $\mathrm{SiO}_{4}$ tetrahedral individually with a set of two silica atom and one oxygen atom in a center [29].

\subsection{Bentonite clay}

Bentonite basically consist of a mineral montmorillonite and having the composition of aluminum Phyllosilicates. Alternation of glassy materials (volcanos) forms the bentonite clay. Bentonite clay minerals having the variety of other minerals such as: kaolin, mica and attapulgite, illite along with quartz, feldspar and gypsum. The general molecular formula of bentonite clay is $\mathrm{Al}_{2} \mathrm{H}_{2} \mathrm{Na}_{2} \mathrm{O}_{13} \mathrm{Si}_{4}$. Mainly two types of bentonite clay are found; sodium and calcium bentonite. Sodium bentonite clay having one $\mathrm{Na}+$ ions as an exchangeable ion with single water layer particle with swelling property on other hand calcium bentonite clay is a non-swelling type clay in which $\mathrm{Ca}^{+}$as an exchangeable cation with a presence of double layer of water. Bentonite clay have several application in the different area. It can be used in oil adsorption, 

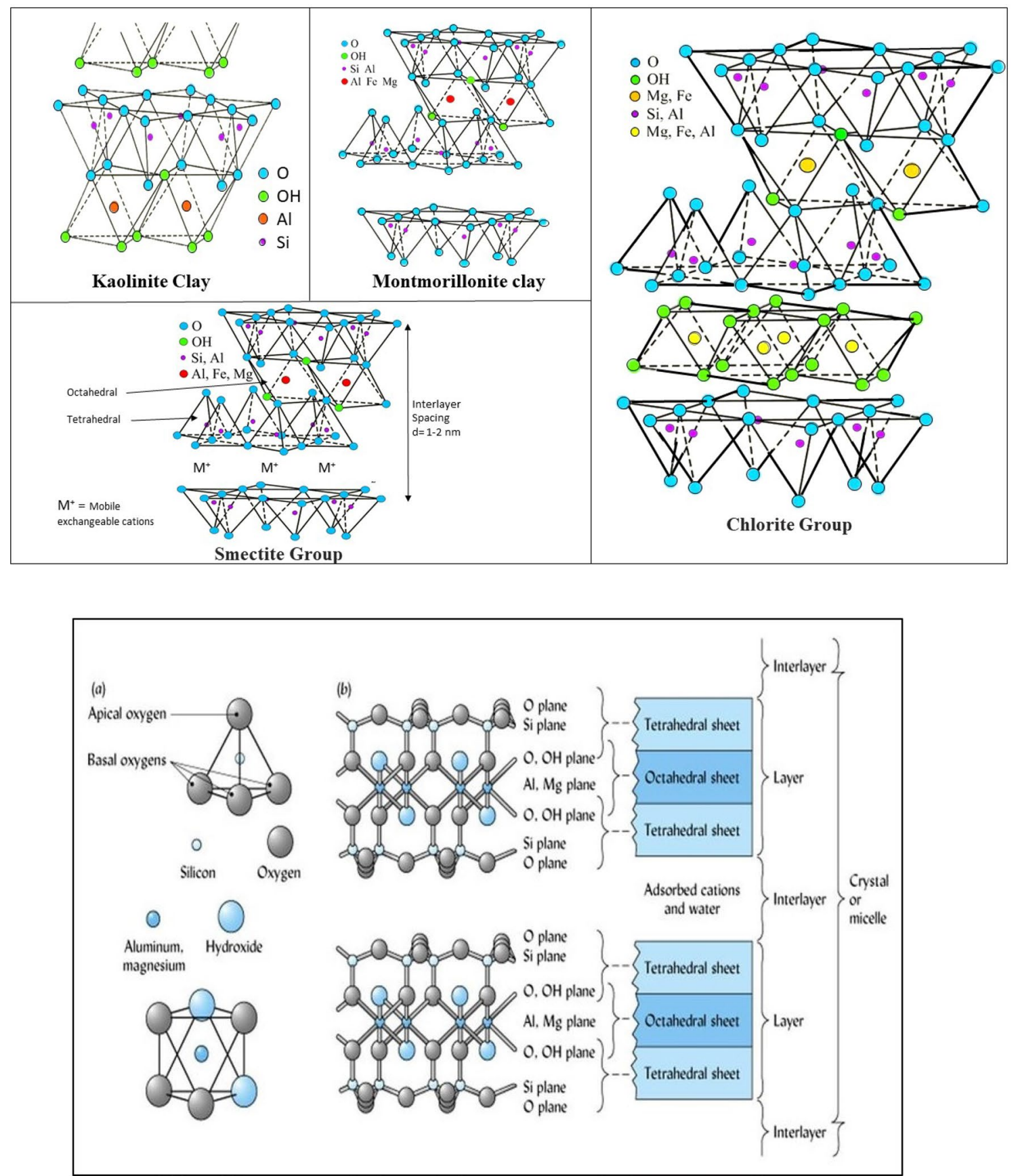

Fig. 4 Structural geometry of common clay minerals [31]

pelletizing, cast iron industry and odor and liquid adsorbent. One of the major application of bentonite is waste water treatment, it is used as adsorption/absorption material. Bentonite naturally have the low permeability, which makes bentonite as a sealing material for the landfills construction and rehabilitation to control the contamination of ground water from pollutants [89].

\section{Methods for preparation of clay nano-composites}

According to the Zapata [131], synthesis of the nanocomposites can be achieved by the 3 different routes:

1. Solution Blending

2. Molten State 


\section{Polymerization}

Out of these methods of preparation of nano-clays, Polymerization process have some novel advantages such as:

- Enhanced compatibility of clay with other matrix of polymer

- Improved dispersion quality of the clay mineral

- An effective way to synthesized metallocene nanocomposite

Polymerization process develop the spacing between clay layers which increases gap in the structure of clay particle and changes the state of clay mineral from intercalated to exfoliate.

\section{Mechanism of nano-clay adsorption in water treatment}

Recent studies showed that nano-clay as an adsorbent received more consideration for adsorption of various contaminants from water due to process of surface sorption mechanism. It has been discussed earlier that the nanoclay is non-toxic, low-cost material with the high potential of ion-exchange and abundantly present in nature. As already discussed in the classification of clay minerals (6.2) different types of clays such as bentonite [11], kaolinite [47], illite [21], sepiolite [62], montmorillonite [41] and pyrophyllite [34] have been reported to be efficient for the elimination of pollutants from water. Nanoclay minerals having the high specific surface area and high sorption capacity that provides high structural and chemical stability towards the adsorption of organic and inorganic contaminants.

Adsorption process at the surface of the clay is directly linked to the charge chemistry present at the surface. A different number of the mechanism have been reported for the sorption of metals ions by the nanoclay minerals like-Physical adsorption, Micro-precipitation (involves an exchange of ions at permanent charged sites and development of compounds (complexes) at the edge sites with hydroxyl groups and chemisorption [14, 53] (Figs. 5, 6). The formation of organo clay can be achieved by the exchange of cations with organic molecules [111]. Some of the factors which plays a major role in the adsorption process are explained below.
Fig. 5 Mechanism of heavy metal adsorption at the surface of Nanoclay

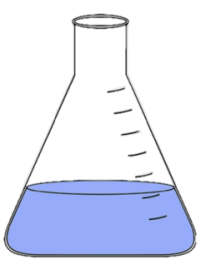

Nano-Clay Adsorption mechanism
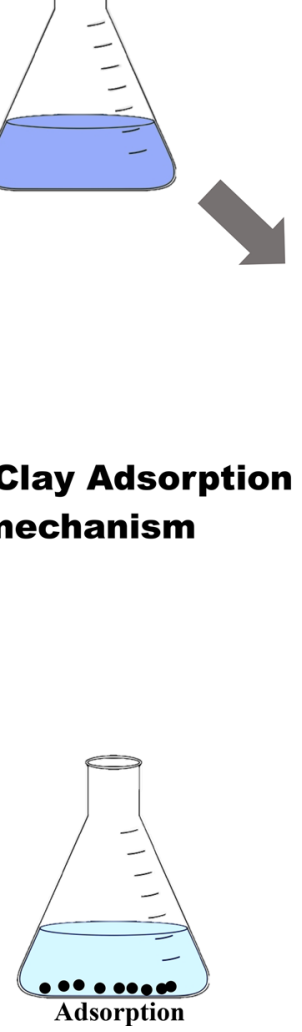
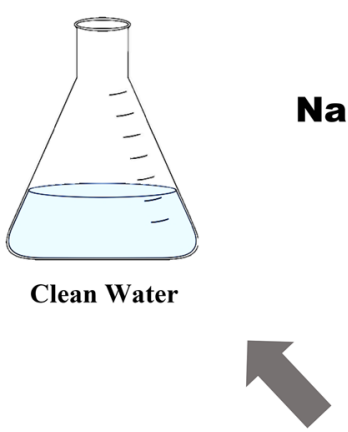

Clean Water

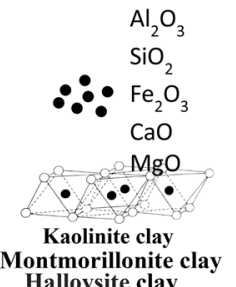

Halloysite clay

Vermiculite clay
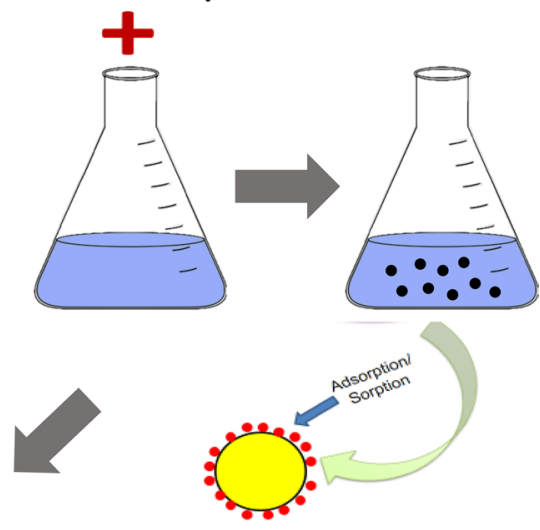
Adsorption of pollutants at different surface locations of nano-clay

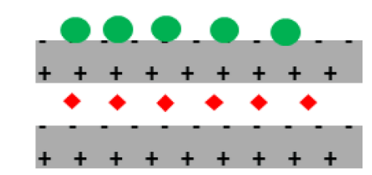

- Clay Cation Adsorbed molecule
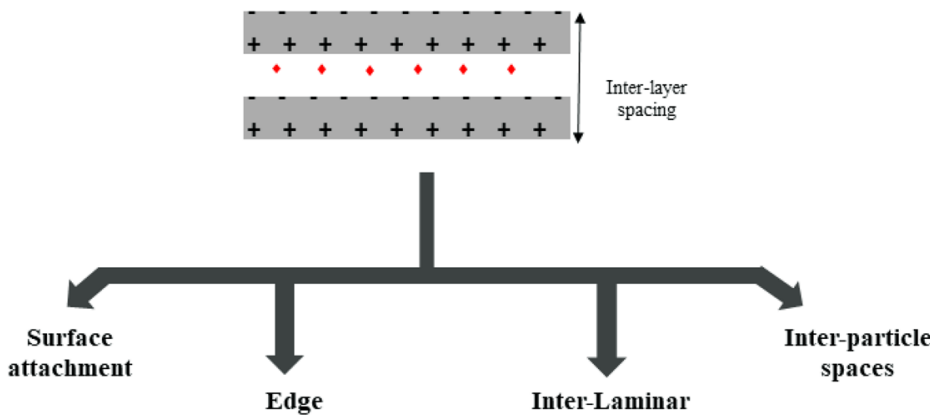

attachment spaces
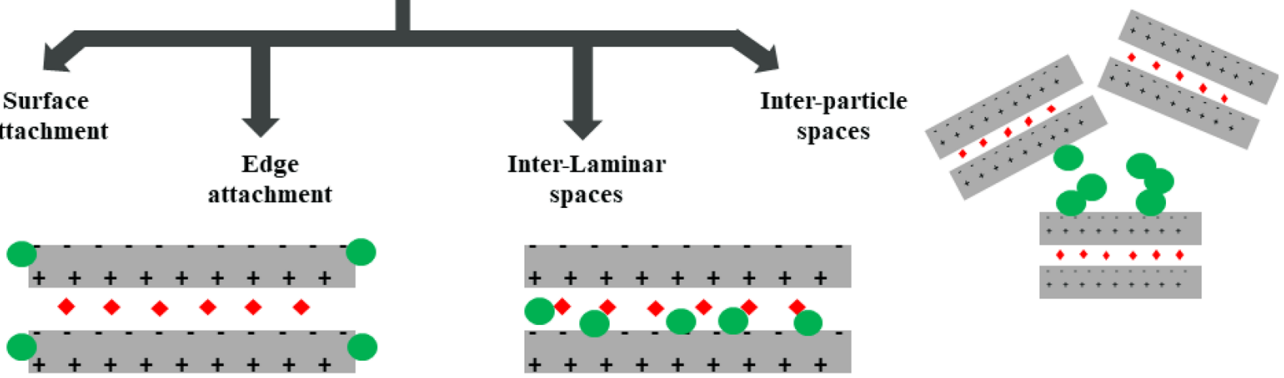

Fig. 6 Adsorption of pollutants at the different surface locations of nano-clay

\subsection{Effective factors for adsorption process}

Some of the major factors required for the better adsorption of molecules in the sorbent, are discussed below.

\subsubsection{Innate surface properties of nano-adsorbent}

Figure 2 represents the mechanism of surface adsorption. Nature and presence of active sites at the surface of nanoadsorbent is a key challenge [88]. Some of the basic factors are required for the proper functioning of nano-adsorbent in any solution and substract are high surface area, and location of atoms on the surface. High potential of adsorption, maximum resistance property and high surface binding energy at all location of the molecules requires surface attachment, inner side attachment, and edge attachment (Fig. 6). These characteristics of the nano-adsorbent lead to the major portion of the atoms and molecules adsorbing at the surface and on the interfaces to enhance the significant availability and affinity, surface improvement and increasing the number of potential sites, ultimately increasing the surface energy towards the removal of a specific pollutant [86].

\subsubsection{External chemistry of nano-adsorbent}

Mechanism of external adsorption of nanoadsorbent implicates the use of different functional groups and different variations on the adsorbent surface. Coupling process of different nanoparticles with a variety of external process of functionalization leads towards the greater success in adsorption properties. Besides this, surface functionalization process also prevent from the loss of aggregation of nanoparticle and provides their selectivity. The functionalization of the different groups at the surface of the nanoparticles increases the adsorption capacity of the Nano adsorbent [93].

A study by Vukovic et al. [124] on multiple wall carbon nano tube functionalization with ethylenediamne $\left(\mathrm{C}_{2} \mathrm{H}_{4}\right.$ $\left.\left(\mathrm{NH}_{2}\right)_{2}\right)$ by the formation of amide bond with carboxyl groups on external layer of carbon nanotube explained that $\mathrm{pH}$ of solution plays a significant role in sorption process. $\mathrm{pH}$ plays a key role in the degree of ionization, speciation of metallic ion in the aqueous solution for the removal of Cd II. Another factor that directly affects the role of functionalization of organic groups on surface of nanomaterials or nano-adsorbent is the Zeta Potential, it is usually calculated to check the dispersion of nanomaterials in the liquid and to determine the charges present on the surface of colloids and molecules. It is called electrophoretic mobility (motion of ions within a solution).

\section{Applications of nano-clay minerals}

Clay minerals are composed of layered silicates with the combination of two elements-silicon and oxygen and having several applications in numerous fileds of environment. Nano-clays are non-toxic and non-combustible materials, which therefore used in manufacturing process of different materials such as flame and fire protection for plastics. Clay minerals finds more attention in industrial applications used as a raw material in construction for e.g. Clay minerals in natural lime rock or in the clay or shale mixed with limestone would contribute $\mathrm{SiO}_{2}, \mathrm{Al}_{2} \mathrm{O}_{3}$ and possibly $\mathrm{Fe}$, alkalis, and alkaline earths depending on the 
identity of clay minerals for the manufacture of Portland cement. Kaolinite is best suitable for the manufacture of white Portland cement [92].

Phlogopite, illite, and glauconitic clays are used as agro mineral additive to enhance soil fertility for crop production because of their high content of potassium. Clays composed of montmorillonite and kaolinites are used in pesticide preparations as diluents to enhance even the dispersion of the toxicant and the retention of the pesticide by plants. Especially kaolinites, have been used for centuries in pharmaceutical preparations of intestinal adsorbent drugs and other therapeutically useful applications. Clays are very valuable prime raw materials in the manufacture of several ceramic products for example in ceramic building materials (bricks, tiles, stoneware pipes, domestic sanitary wares, and fittings for sewage and drainage) and domestic ceramics (table wares, dinner ware, flower vases, dental wares, e.g. artificial teeth, etc.) In clarification of portable water, colloidal matter is removed by filtration and/or sedimentation processes. Alum is usually used to flocculate the colloidal materials to enhance its settling and filtration rate.

Films food packaging and plastic surfaces modifications are some other areas for nanoclay application as plastic additives. The addition of nanoclay to the plastics leads to higher tensile strength, improved barrier and abrasion properties, excellent surface qualities, low thermal expansion and very good flow and processing properties. This outstanding property profile qualifies plastic-nanoclaycomposites as an interesting alternative to conventionally reinforced materials. In most of the cases, research studies have shown that nano-clay clays are best suitable for water clarification purpose because of possessing the essential dispersion and adsorptive properties in water treatment; further, clays at the same time can be used to reduce and remove bad odor and taste in water and also for softening of water. Removal of metal and inorganic contaminants from waste water due to high adsorption capacity
Fig. 7 Different applications of clay minerals

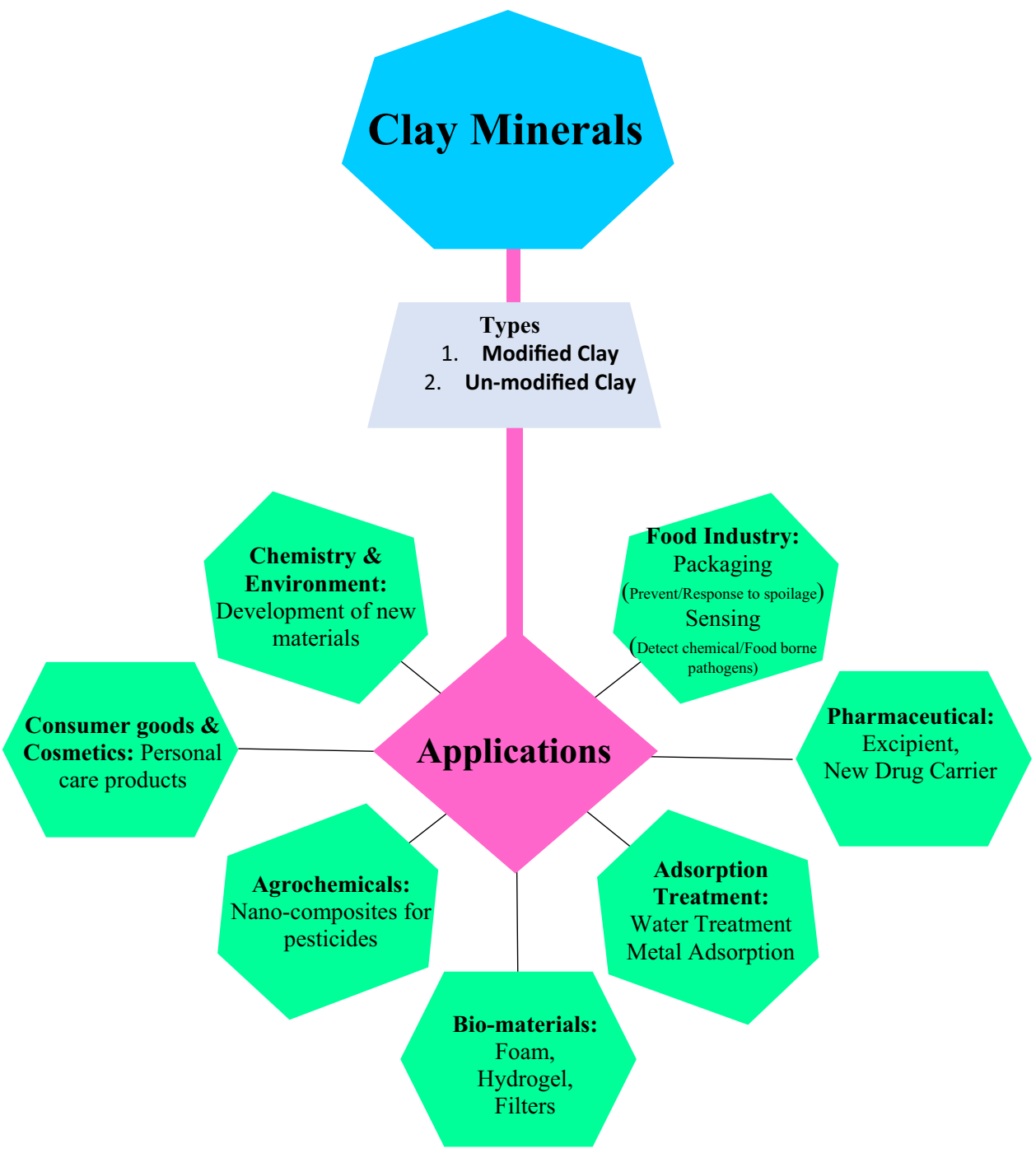


of nanoclay is the key application in the environmental field [110]. Several applications of clay minerals have been shown in the Fig. 7.

\section{Summary}

There is a huge requirement of cost-effective advanced technologies for water purification, specifically to ensure the quality of drinking water by removing micro pollutants, and strengthening the industrial production process. Development in nanoscience and engineering are considered as novel opening to develop innovative, eco-friendly and cost-effective water treatment technologies. The unique physico-chemical characteristics of nano-materials caught a greater attention for the treatment of water in the current scenario. As of late, modified nano-clays and clay as adsorbents are gaining extensive attention because of their greater potential for the removal of contaminants from different matrices.

Clay and clay minerals have been explored as the adsorbents for the removal of heavy metals from aqueous solution. The advantages of using clay minerals as alternative adsorbents for removal of heavy metals includes high ion sorption/exchange capacity, low permeability, swelling ability, chemical and mechanical stability, and large specific surface area. Different types of clay minerals have been tested for the removal of heavy metal ions from water and wastewater. Some of the recent studies on utilization of clay minerals as adsorbent for water purification are discussed in the manuscript and a glimpse of it is given below.

Modified bentonite clay with $\mathrm{HCL}$ was used by Hajjaji and El Arfaoui [36] for the removal of Zn (II) and Kul and Koyuncu [56] used same modified (bentonite with $\mathrm{HCL}$ ) for the removal of $\mathrm{Pb}(\mathrm{II})$; likewise Eren et al. [23] used pillared bentonite by $\mathrm{MnCl}_{2}$ for the removal of $\mathrm{Pb}$ (II) and all the studies concluded that bentonite clay was very effective for the adsorption of heavy metal in water treatment. Tirtom et al. [115], worked on removal of $\mathrm{Ni}(\mathrm{II})$ and $\mathrm{Cd}$ (II) by chitosan-bentonite clay having cross-linked structure to enhance efficiency of adsorbent for adsorption of contaminants from water.

Kaolin clay are the oldest clay mineral used in different environmental and industrial applications. In Tang et al. [112] worked on removal of Cd (II) from the water by influencing certain parameters such as- increasing initial concentration, $\mathrm{pH}$, equilibrium time, dosage and temperature on the adsorption performance; similar type of findings have been reported by Fathima et al. [24] on kaolin-supported bacterial biofilm of Bacillus species for removal of $\mathrm{Cr}(\mathrm{III})$ [16]. Removal of $\mathrm{Cr}$ (VI) from aqueous solution by onseeds of Artimisa absinthium was performed by Rao et. al. [103] and results showed higher removal efficeincy and Artimisa proved as a novel plant material for cadium removal. Unuabonah et al. [120] performed the experiment on polyvinyl alcohol modified kaolinite clay for the removal of $\mathrm{Pb}$ (II) from water and concluded that modified natural clay (kaolinite) as a good adsorbent for removal of $\mathrm{Pb}$ (II). Sari and Tuzen [106], investigated the efficiency of on pillared kaolinite using $\mathrm{MnO}_{2}$ for the removal of $\mathrm{Cd}(\mathrm{II})$ as well as removal of $\mathrm{Pb}(\mathrm{II})$ and $\mathrm{Cd}(\mathrm{II})$; also studied by Mascia et al. [75] and the studies resulted in establishing the high removal efficiency of nano-clay [101].

It has be seen that some of the natural clay like- Montmorillonite show significant dye and metal removal capacities; while others still need modifications in order to enhance its adsorption capacities. Study on montmorillonite clay performed by several researchers by activating adsorption capacity [5], Pillared montmorillonite by $\mathrm{TiCl}_{2}$, [87]. Chitosan- montmorillonite beads were prepared by crosslinking with pentasodium tripolyphosphate for the removal of $\mathrm{Cu}$ (II) studied by Pereira et al. [95]. Some more toxic metal removal studies was performed by Dos Santos et al. [20] and Wang et al. [127]. For the removal of Co (II) by modified chitosan-montmorillonite and removal of $\mathrm{Hg}$ (II) by influence of $\mathrm{pH}$, ionic strength and treatment with different cations [69].

Similarly, the mixture of smectite, illite, calcite used for the removal of $\mathrm{Cu}$ (II) and Zn (II) evaluated the adsorption capacity of three natural clay [85]. Palygorskite clay was also found effective for the removal of $\mathrm{Cd}$ (II) through $\mathrm{HCL}$ modification studies [28].

Pranoto and Fathoni [97], used clay ceramic filter for the removal of $C d$ by adsorption by model reactions study with the combination of clay and andisol composition. Andisol/clay mixture was effective in minimizing the concentration of cadmium in water by $98.9 \%$. Like-wise Kalebaila et al. [48] also did the same experiment with photo catalysts by modifying the clay with inorganic ions using the sol-gel synthetic process and concluded adsorption process with a good adsorbents will be cost effective in terms of conservation. Table 1 shows summary of different work done by researchers from last several years till the current scenario for treatment of variety of contaminants using nano-clays.

Advances in clay to make nano-composites clay materials after modification in structural form are used for water treatment [122]. Adsorption offers a wide range of bacterial and organic removal with complete removal of pathogens. Study on clay based nano-composite by Das et al. [19], concluded that Surface modification in halloysite nano-clays for two dissimilar organosilanes makes it beneficial for the adsorption of toxic materials and proved that 


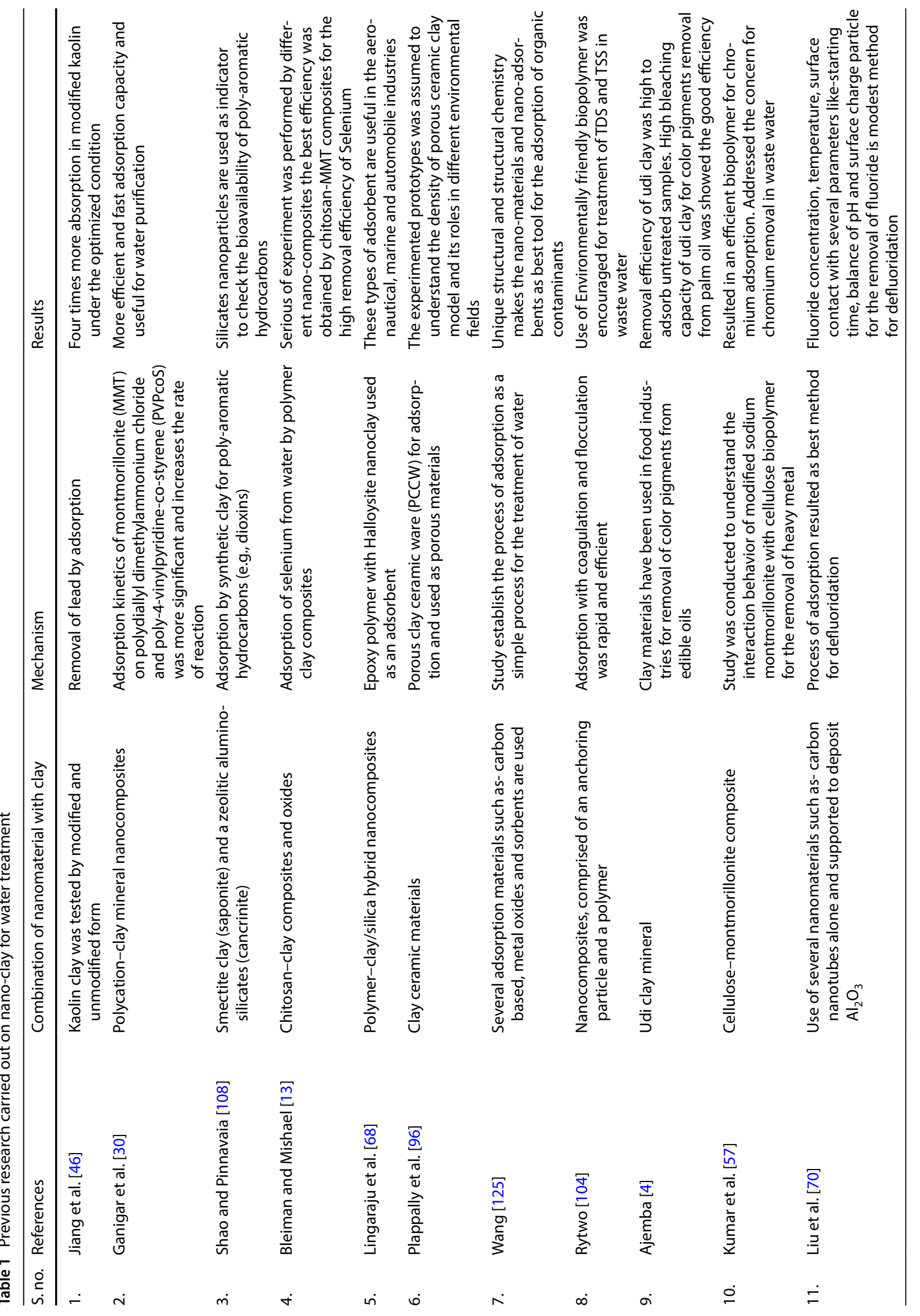




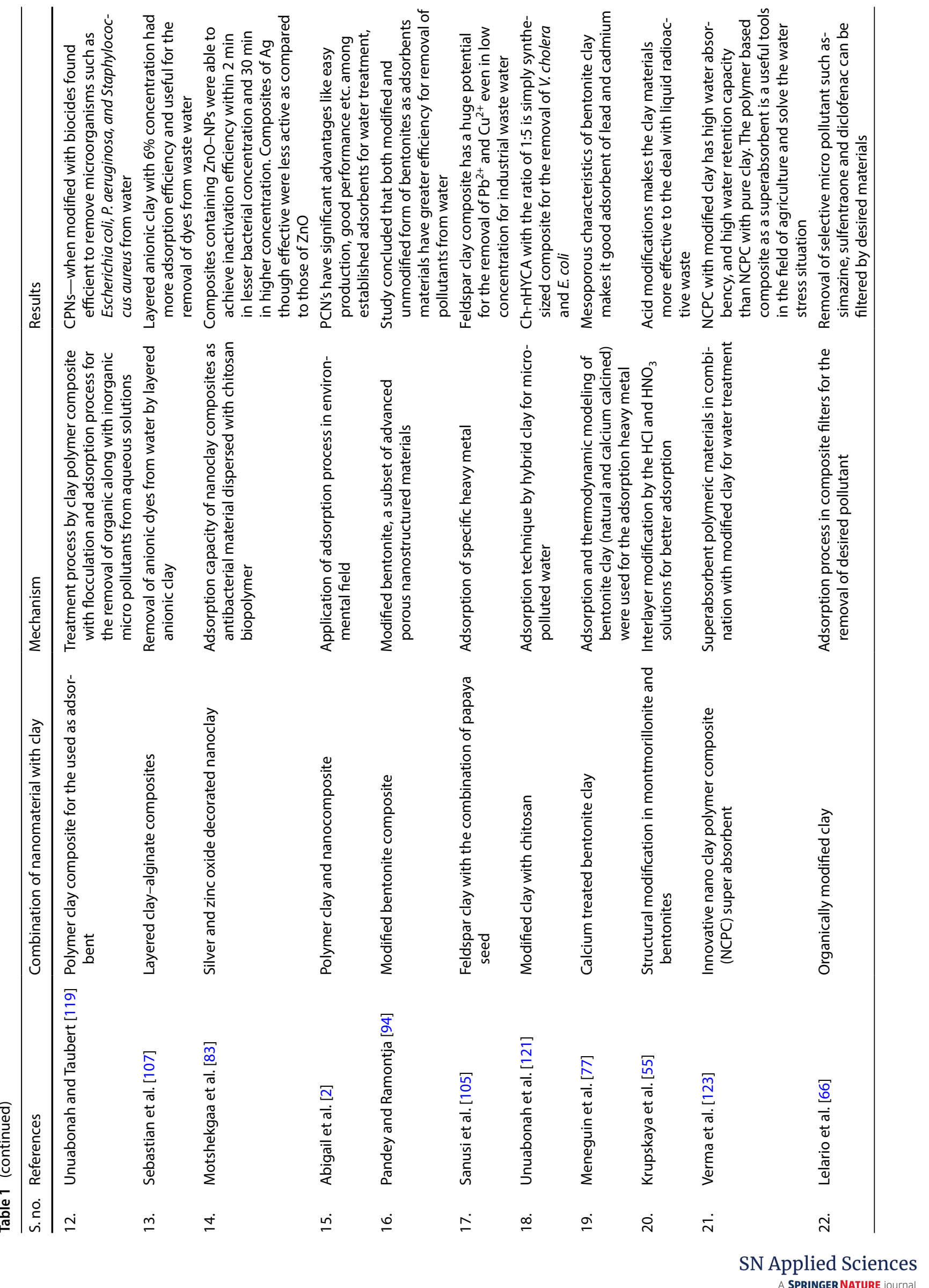




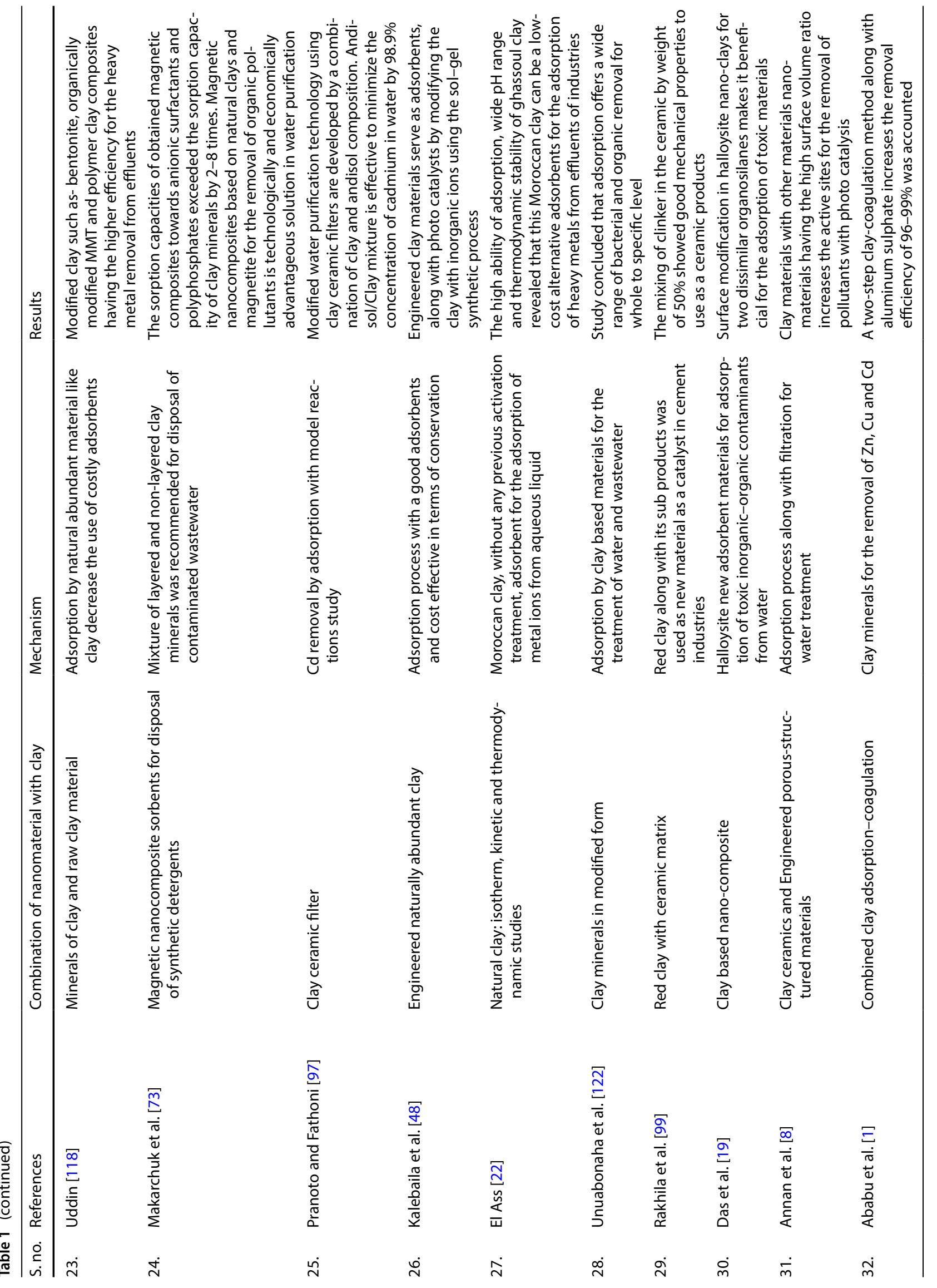




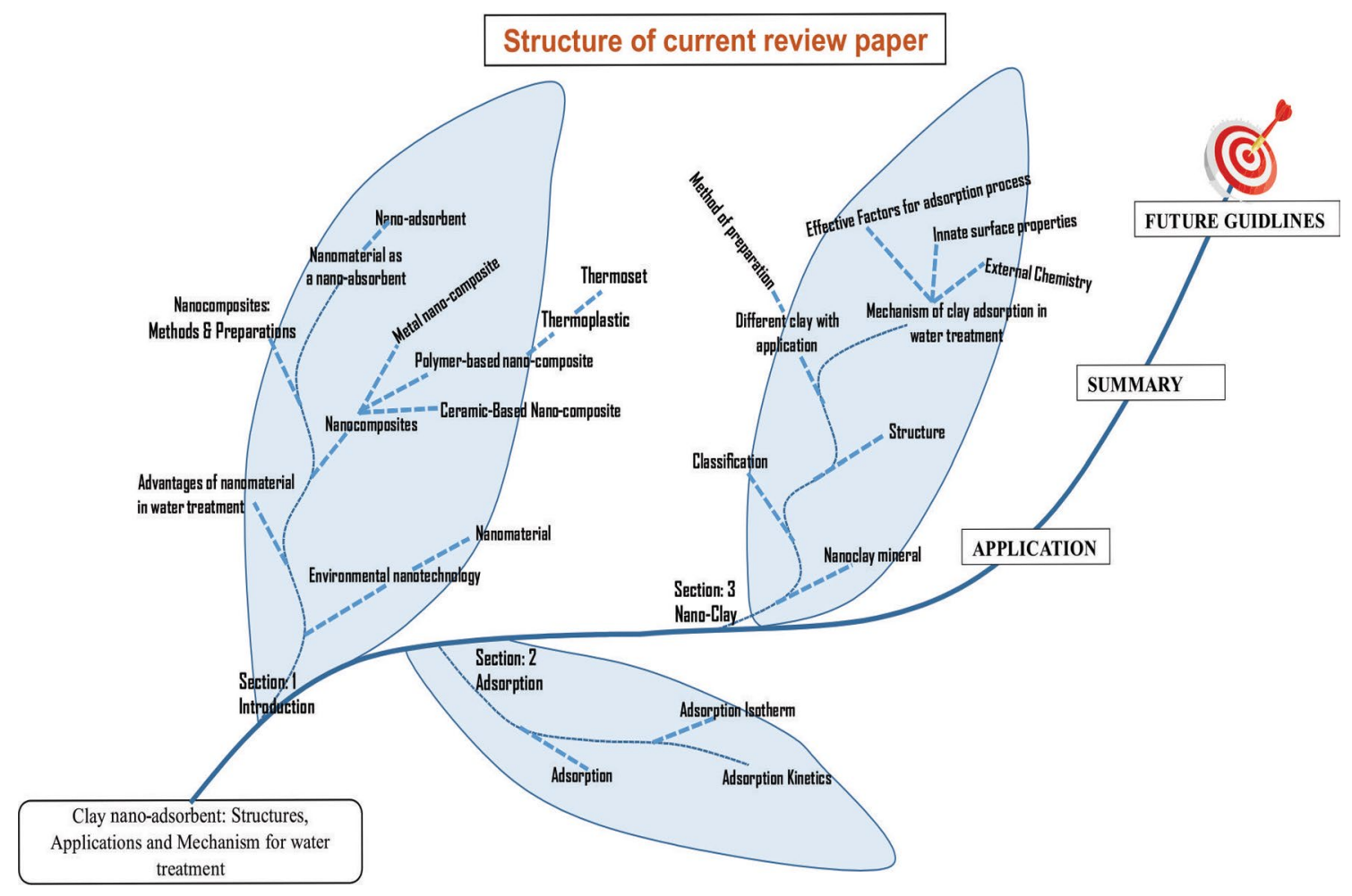

Fig. 8 Structure of current review paper

halloysite is a new adsorbent materials for adsorption of toxic inorganic-organic contaminants from water.

Combined clay adsorption-coagulation study by Ababu et al. [1] concluded that with two-step clay-coagulation method along with aluminum sulphate increases the removal efficiency of $\mathrm{Zn}, \mathrm{Cu}$ and $\mathrm{Cd}$ to $96-99 \%$.

Recent study by Merah and Mohamed [78] worked on the mechanism of nano clay and its water uptake, they used synthesized unsaturated polyester/nanoclay (UP/NC) composites to understand the mechanism of nanoclay and concluded that the addition of I.30E nanoclay enhanced the hydrophobicity of the nanocomposite with a maximum improvement of about $40 \%$ at $4 \mathrm{wt} . \%$ of nano clay loading. Flexural test results revealed relative degradation in the flexural properties of neat UP and UP/NC, due to moisture uptake. However, the reduction in flexural properties was found to be minimal at the optimum nanoclay loading of $3 \mathrm{wt} . \%$. In this paper, we have elaborated on the types of nano-clays that are common and their associated benefits with reference to water treatment with the combination of nanotechnology. A Full structural flow chart depicting the entire concept dealt in the manuscript has been represented in Fig. 8.

\section{Conclusion and future considerations}

Composites of clay used for coating with the naturally synthesized polymer have greater potential for the treatment of water. As discussed in the literature, the efficiency of clay minerals could be increased by integration of new materials at nanoscale for manufacturing of stable clay nano-composites with advance properties.

Polymer-clay nano-composites getting more attention from recent few years in different areas like in automotive Industry (polymers reinforced with carbon nano-tubes with exfoliated clay are being used for the manufacturing of automatic parts), Barrier layers in packing (polyamide- 6 clay nanocomposites are mostly used in high barrier packing for food). These nano-composites made good combination of barrier properties with the perfect ratio of $\mathrm{O}_{2}$ and $\mathrm{CO}_{2}$, High mechanical and thermal characteristics (manufacturing of flame retardants), Textiles Industry (for the commercialization of fibers and Coloring of dyes) [33]. On the other hand, there is immediate need for advanced materials for the elimination of emerging pollutants existing in drinking water because present technologies do not have much efficiency for the removal of prevailing pollutants from the water. Modifications in the surface geometry and increment in the surface area make them a compatible material for different applications. More experimental studies are required to produce different results in the area 
of polymer clay nano-composites for treatment and purification of water. The development of new material and composites for decontamination of water is required for intended uses. Besides this, production capacity of water filter can be increased by the application of nanotechnology because these nanocomposites offers high surface to volume ratio with the presence of number of active sites for the removal of pollutants. Therefore, adsorption is one of the great approaches for the complete removal of contaminants and development of new water purification systems with low cost. Further research is, therefore, required for the development of an appropriate understanding of the structure, property and formulation relationship in nanocomposites for the better output of the water systems. Nano-clay have been proved to be the best materials for the manufacturing of new materials and provide cost effective sustainable solutions to different industries for environmental health and safety. Replacement of conventional methods for purification of water with advanced cost-effective materials have been proven as a promising tool in water purification process all-round the globe.

\section{Compliance with ethical standards}

Conflict of interest The authors declare that they have no conflict of interest.

\section{References}

1. Ababu T, Tiruneh T, Debessai Y, Bwembya Gabriel C, Nkambule Stanley J (2018) Combined clay adsorption-coagulation process for the removal of some heavy metals from water and waste water. Am J Environ Eng 8(2):25-35. https://doi. org/10.5923/j.ajee.20180802.02

2. Abigail K et al (2016) Polymer-clay nanocomposites and composites: structures, characteristics, and their applications in the removal of organic compounds of environmental interest. Med Chem (Los Angeles) 6(3):201-210

3. Ahmeda DS, Haiderb AJ, Mohammad MR (2013) Comparesion of functionalization of multi walled. Carbon nanotubes treated by oil olive and nitric acid and their characterization. Energy Proc 36:1111-1118. https://doi.org/10.1016/j.egypr 0.2013 .07 .126

4. Ajemba RO (2012) Modification of the physico-chemical properties of udi clay mineral to enhance its adsorptive capacity. Adv Appl Sci Res 3(4):2042-2049

5. Akar ST, Yetimoglu Y, Gedikbey T (2009) Removal of chromium (VI) ions from aqueous solutions by using Turkish montmorillonite clay: effect of activation and modification. Desalination 244(1-3):97-108

6. Ali I (2012) New generation adsorbents for water treatment. Chem Rev 112(10):5073-5091. https://doi.org/10.1021/cr300 133d

7. Ali I, Gupta VK (2007) Advances in water treatment by adsorption technology. Nat Protoc 1:2661-2667

8. Annan E, Agyei-Tuffour B, Bensah YD, Konadu DS, Yaya A, Onwona-Agyeman B, Nyankson E (2018) Application of clay ceramics and nanotechnology in water treatment: a review. Cogent Eng 5:1476017. https://doi.org/10.1080/23311 916.2018.1476017

9. Azonano (2009) Nanocomposites. http://www.azonano.com/ details.asp?ArticlelD=1147. Accessed 23 June 2013

10. Becher PF (1991) Microstructural design of toughened ceramics. J Am Ceram Soc 74(2):255-269

11. Bereket G, Aroguz AZ, Ozel MZ (1997) Removal of Pb(II), Cd(II), $\mathrm{Cu}(\mathrm{II})$, and $\mathrm{Zn}$ (II) from aqueous solutions by adsorption on bentonite. J Colloid Interface Sci 187:338-343

12. Bhawana P, Fulekar MH (2012) Nanotechnology: remediation technologies to clean up the environmental pollutants. Res J Chem Sci 2(2):90-96

13. Bleiman N, Mishael YG (2010) Selenium removal from drinking water by adsorption to chitosan-clay composites and oxides: batch and columns tests. J Hazard Mater 11963:6. https://doi.org/10.1016/j.jhazmat.2010.07.065

14. Bradbury MH, Bayens B (1999) Modelling the sorption of $\mathrm{Zn}$ and $\mathrm{Ni}$ on Ca-montmorillonite. Geochim Cosmochim Acta 63:325-336

15. Camargo PHC, Satyanarayana KG, Wypych F (2009) Nanocomposites: synthesis, structure, properties and new application opportunities. Mater Res 12(1):1-39

16. Cavaco SA, Fernandes S, Augusto CM, Quina MJ, Gando-Ferreira LM (2009) Evaluation of chelating ion-exchange resins for separating $\mathrm{Cr}$ (III) from industrial effluents. J Hazard Mater 169:516-523

17. Crini G (2005) Recent developments in polysaccharide-based materials used as adsorbents in wastewater treatment. Prog Polym Sci 30:38-70

18. Crini G, Badot P-M (2010) Sorption process and pollution, conventional and non-conventional sorbents for pollutant removal from wastewaters. Presses University, Franche-Comté

19. Das S, Samanta A, Gangopadhyay G, Jana S (2018) Clay-based nanocomposites as recyclable adsorbent toward $\mathrm{Hg}$ (II) capture: experimental and theoretical understanding. Am Chem Soc 3:6283-6292. https://doi.org/10.1021/acsomega.8b00789

20. Dos Santos VCG, Grassi MT, Abate G (2015) Sorption of Hg(II) by modified $\mathrm{K} 10$ montmorillonite: influence of $\mathrm{pH}$, ionic strength and the treatment with different cations. Geoderma 237:129-136

21. Echeverria JC, Zarranz I, Estella J, Garrido JJ (2005) Simultaneous effect of $\mathrm{pH}$, temperature, ionic strength, and initial concentration on the retention of lead on illite. Appl Clay Sci 30:103-115

22. El Ass K (2018) Adsorption of cadmium and copper onto natural clay: isotherm, kinetic and thermodynamic studies. Glob NEST J 20:1-10

23. Eren E, Afsin B, Onal Y (2009) Removal of lead ions by acid activated and manganese oxide-coated bentonite. J Hazard Mater 161(2-3):677-685

24. Fathima A, Rao JR, Nair BU (2012) Trivalent chromium removal from tannery effluent using kaolin-supported bacterial biofilm of Bacillus $s p$ isolated from chromium polluted soil. J Chem Technol Biotechnol 87(2):271-279

25. Floody MC, Theng B, Reyes P, Mora M (2009) Natural nanoclays: applications and future trends-a Chilean perspective. Clay Miner 44:161-176

26. Forstinus NO, Ikechukwu NE, Emenike MP, Christiana AO (2015) Water and waterborne diseases: a review. Int J Trop Disease Health 12(4):1-14. https://doi.org/10.9734/ijtdh/2016/21895

27. Freundlich HMF (1906) Over the adsorption in solution. J Phys Chem 57:385-470 
28. Frini-Srasra N, Srasra E (2010) Acid treatment of south Tunisian palygorskite: removal of $\mathrm{Cd}$ (II) from aqueous and phosphoric acid solutions. Desalination 250(1):26-34

29. Galan E (1996) Properties and applications of palygorskitesepiolite clays. Clay Miner 31:443-453

30. Ganigar R, Rytwo G, Gonen Y, Radian A, Mishael YG (2010) Polymer-clay nanocomposites for the removal of trichlorophenol and trinitrophenol from water. Appl Clay Sci 49(1-15):311-316. https://doi.org/10.1016/j.clay.2010.06.015

31. Grim RE (1962) Applied clay mineralogy. McGraw Hill Press, New York City

32. Grim RE (1968) Mineralogy, 2nd edn. McGraw-Hill Press, New York, p 596

33. Gupta B, Lacrampe M-F, Krawczak P (2005) Polyamide-6/clay nanocomposites: a critical review. Polym Polym Compos 14(1):13-38

34. Gupta N, Prasad M, Singhal N, Kumar V (2009) Modeling the adsorption kinetics of divalent metal ions onto pyrophyllite using the integral method. Ind Eng Chem Res 48(4):2125-2128

35. Gupta VK, Kumar R, Nayak A, Saleh TA, Barakat MA (2013) Adsorptive removal of dyes from aqueous solution onto carbon nanotubes: a review. Adv Colloid Interface Sci 193:24-34

36. Hajjaji M, El Arfaoui H (2009) Adsorption of methylene blue and zinc ions on raw and acid-activated bentonite from Morocco. Appl Clay Sci 46(4):418-421

37. Hamid RG, Hasan P, Abdolhamid T, Kavoos D, Babak G, Vali A, Amin G (2017) Linear and nonlinear two-parameter adsorption isotherm modeling: a case-study. Int J Eng Sci. https://doi. org/10.9790/1813-0609010111

38. Hamzaoui M, Bestani B, Benderdouche N (2018) The use of linear and nonlinear methods for adsorption isotherm optimization of basic green 4-dye onto sawdust-based activated carbon. J Mater Environ Sci 2508(4):1110-1118

39. Harmer M, Chan HM, Miller GA (1992) Unique opportunities for microstructural engineering with duplex and laminar ceramic composites. J Am Ceram Soc 75(2):1715-1728

40. Hurlbut CS, Klein C (1977) Manual of mineralogy. Wiley, New York

41. Ijagbemi CO, Baek MH, Kim DS (2009) Montmorillonite surface properties and sorption characteristics for heavy metal removal from aqueous solutions. J Hazard Mater 166:538-546

42. Imran S, Alam K, Beaumont N (2014) Reinterpreting the definition of sustainable development for a more ecocentric reorientation. Sustain Dev 22(2):134-144

43. Ismadji S, Soetaredo FE, Ayucitra A (2015) Clay materials for environmental remediation, in green chemistry for sustainability. Springer, Berlin. https://doi.org/10.1007/978-3-319-16712 $-1 \_2$

44. Jagtap S, Yenkie MKN, Labhsetwar N, Rayalu S (2011) Defluoridation of drinking water using chitosan based mesoporous alumina. Microporous Mesoporous Mater 142(2-3):454-463. https://doi.org/10.1016/j.micromeso.2010.12.028

45. Jain KK (2012) Nanotechnology and water. Contemp Mater 1(3):26-30. https://doi.org/10.7251/COM1201026J

46. Jiang $M$, Wang $Q$, Jin $X$, Chen Z, Chen Z (2009) Removal of $\mathrm{Pb}$ (II) from aqueous solution using modified and unmodified kaolinite clay. J Hazard Mater 170(1):332-339. https://doi. org/10.1016/j.jhazmat.2009.04.092

47. Jiang $M$, Jin X, Lu X, Chen Z (2010) Adsorption of Pb(II), Cd(II), $\mathrm{Ni}(\mathrm{II})$ and $\mathrm{Cu}(\mathrm{II})$ onto natural kaolinite clay. Desalination 252:33-39

48. Kalebaila KK, Maseka KJ, Mbulo M (2018) Selected adsorbents for removal of contaminants from wastewater: towards engineering clay minerals. Open J Appl Sci 8:355-369

49. Kennedy BA (1990) Surface mining. society for mining, metallurgy, and exploration, 2nd edn. Port City Press, Pikesville
50. Khan MA, Uddin MK, Bushra R, Ahmad A, Nabi SA (2014) Synthesis and characterization of polyaniline $\mathrm{Zr}$ (IV) molybdophosphate for the adsorption of phenol from aqueous solution. React Kinet Mech Catal 113:499-517

51. Kickelbick G (2003) Concepts for the incorporation of inorganic building blocks into organic polymers on a nanoscale. Prog Polym Sci 28(1):83-114

52. Kojima Y, Usuki A, Kawasumi M, Okada A, Karauchi T, Kamigaito O (1993) J Pol Sci Part A Pol Chem 31:983

53. Kraepiel AML, Keller K, Morel FMM (1999) A model for metal adsorption on montmorillonite. J Colloid Interface Sci 210:43-54

54. Kruis FE, Fissan H, Peled A (1998) Synthesis of nanoparticles in the gas phase for electronic, optical and magnetic applications-a review. J Aerosol Sci 29(5-6):511-535. https://doi. org/10.1016/S0021-8502(97)10032-5

55. Krupskaya V, Zakusin S, Tyupina E, Dorzhieva O, Zhukhlistov A, Belousov P, Timofeeva M (2017) Experimental study of montmorillonite structure and transformation of its properties under treatment with inorganic acid solutions. Minerals 7:49. https://doi.org/10.3390/min7040049

56. Kul AR, Koyuncu $H$ (2010) Adsorption of $\mathrm{Pb}(\mathrm{II})$ ions from aqueous solution by native and activated bentonite: kinetic, equilibrium and thermodynamic study. J Hazard Mater 179(1-3):332-339

57. Kumar KS, Kalidhasan S, Rajesh V, Rajesh N (2012) Application of cellulose-clay composite biosorbent toward the effective adsorption and removal of chromium from industrial wastewater. Ind Eng Chem Res 51:58-69. https://doi.org/10.1021/ ie201349h

58. Lagergren SY (1898) Zur Theorie der sogenannten adsorption gelöster Stoffe, Kungliga Svenska Vetenskapsakad. Handlingar 24:1-39

59. Lange FF (1973) Effect of microstructure on strength of si3n4sic composite system. J Am Ceram Soc 56(9):445-450

60. Langmuir I (1916) The constitution and fundamental properties of solids and liquids. Part I. Solids. J Am Chem Soc 38(11):2221-2295

61. Langmuir I (1961) Nobel lecture. Surface Chemistry, vol 11, no 1. Philosophical Library, New York, Pergamum Press, p 74

62. Lazarević S, Janković-Častvan I, Jovanović D, Milonjić S, Janaćković DJ, Petrović R (2007) Adsorption of Pb2 +, $\mathrm{Cd} 2+$ and $\mathrm{Sr} 2+$ ions onto natural and acid-activated sepiolites. Appl Clay Sci 37(1-2):47-57

63. Lee SM, Tiwari D (2012) Organo and inorgano-organo-modified clays in the remediation of aqueous solutions: an overview. Appl Clay Sci 59-60:84-102. https://doi.org/10.1016/j. clay.2012.02.006

64. Lee J, Mahendra S, Alvarez PJJ (2010) Nanomaterials in the construction industry: a review of their applications and environmental health and safety considerations. ACS Nano 4:3580-3590

65. Lee XJ, Lee LY, Foo LPY, Tan KW, Hassell DG (2012) Evaluation of carbon based nanosorbents synthesised by ethylene decomposition on stainless steel substrates as potential sequestrating materials for nickel ions in aqueous solution. J Environ Sci (China) 24(9):1559-1568. https://doi.org/10.1016/ S1001-0742(11)60987-X

66. Lelario F, IdoGardi Yael M, Dolev Noam, Tomas U, Shlomo N, Laura S, Bufo Sabino A (2017) Pairing micropollutants and clay-composite sorbents for efficient water treatment: filtration and modeling at a pilot scale. Appl Clay Sci 137:225-232. https://doi.org/10.1016/j.clay.2016.12.029

67. Lelieveld J (2001) The chemistry of the future nanotechnology. Alliance for chemical science and technologies in Europe 
68. Lingaraju D, Ramji K, Mohan NBR, Rao U, Rajya L (2011) Characterization and prediction of some engineering properties of polymer_clay/silica hybrid nanocomposites through ANN and regression models. Proc Eng 10:9-18. https://doi.org/10.1016/j. proeng.2011.04.00

69. Liu Y, Yuan D, Yan J, Li Q, Ouyang T (2011) Electrochemical removal of chromium from aqueous solutions using electrodes of stainless steel netscoated with single wall carbon nanotubes. J Hazard Mater 186:473-480

70. Liu W-W, Aziz A, Chai S-P, Mohamed AR, Hashim U (2013) Synthesis of single-walled carbon nanotubes: effects of active metals, catalyst supports, and metal loading percentage. J Nanomater. https://doi.org/10.1155/2013/592464

71. Majeed K, Jawaid M, Hassan A, Bakar AA, Abdul Khalil HPS, Salema AA, Inuwa ME (2007) Nanocomposites: stiffer by design. Nat Mater 6(1):9-11. https://doi.org/10.1038/nmat1 812

72. Majeed K, Jawaid M, Hassan A, Bakar AA, Khalil HA, Salema AA, Inuwa I (2013) Potential materials for food packaging from nanoclay/natural fibres filled hybrid composites. Mater Des 46:391-410. https://doi.org/10.1016/j.matdes.2012.10.044

73. Makarchuk O, Dontsova T, Perekos A, Skoblik A, Svystunov $Y$ (2017) Magnetic mineral nanocomposite sorbents for wastewater treatment. Hindawi J Nanomater. https://doi. org/10.1155/2017/8579598

74. Mansoori GA, Bastami TR, Ahmadpour A, Eshaghi Z (2008) Chapter 2 environmental application of nanotechnology. Ann Rev Nano Res 2:1-73. https://doi.org/10.1142/9789812790 248_0010

75. Mascia M, Vacca A, Palmas S (2015) Effect of surface equilibria on the electrokinetic behaviour of $\mathrm{Pb}$ and $\mathrm{Cd}$ ions in kaolinite. J Chem Technol Biotechnol 90(7):1290-1298

76. Meera Ramrakhiani (2012) Nanostructures and their applications. Recent Res Sci Technol 4(8):14-19

77. Meneguin JG, Moisés MP, Karchiyappan T, Faria SHB, Gimenes ML, de Barros MAS, Venkatachalam S (2017) Preparation and characterization of calcium treated bentonite clay and its application for the removal of lead and cadmium ions: adsorption and thermodynamic modeling. Process Saf Environ Prot. https ://doi.org/10.1016/j.psep.2017.07.005

78. Merah N, Mohamed O (2019) Nanoclay and water uptake effects on mechanical properties of unsaturated polyester. J Nanomater 2019:11. https://doi.org/10.1155/2019/8130419

79. Meyer DE, Upadhyayula VK (2014) The use of life cycle tools to support decision making for sustainable nanotechnologies. Clean Technol Environ Policy 16(4):757-772

80. Miranda-Trevino JC, Coles CA (2003) Kaolinite properties, structure and influence of metal retention on $\mathrm{pH}$. Appl Clay Sci 23:133-139

81. Mitchell GR, Tojeria A (2016) Controlling the morphology of polymers: multiple scales of structure and processing. Springer, Berlin

82. Mohan D, Pittman CU (2006) Activated carbons and low cost adsorbents for remediation of tri and hexavalent chromium from water. J Hazard Mater 137:762-811

83. Motshekgaa SC, Suprakas SR, Onyango MS, Momba MNB (2013) Development of silver and zinc oxide decorated nanoclay containing polymeric composites for water disinfection applications. AIP Conf Proc 1664:070011. https://doi. org/10.1063/1.4918446

84. Murray HH (2007) Occurrences, processing and application of kaolins, bentonites, palygorskite-sepiolite, and common clays. Applied Clay Mineralogy. Elsevier, Amsterdam

85. Musso TB, Parolo ME, Pettinari G, Francisca FM (2014) Cu (II) and Zn (II) adsorption capacity of three different clay liner materials. J Environ Manage 146:50-58
86. Muzammil A, Miandad R, Waqas M, Gehany F, Barakat MA (2016) Remediation of wastewater using various nanomaterials. Arab J Chem, Arabian J. https://doi.org/10.1016/j.arabj c.2016.10.004

87. Na P, Jia X, Yuan B, Li Y, Na J, Chen Y, Wang L (2010) Arsenic adsorption on Ti-pillared montmorillonite. J Chem Technol Biotechnol 85(5):708-714

88. Nassar NN (2012). Iron oxide nanoadsorbents for removal of various pollutantsfrom wastewater: an overview. Appl Adsorbents Water Pollut Control. https://www.researchgate.net/ publication/236186356

89. Nazir MS, Kassim MHM, Mohapatra L, Gilani MA, Raza MR, Majeed K (2016) Characteristic Properties of nano-clays and characterization of nano-particulates and nanocomposites. Nanoclay Reinf Polym Compos Eng Mater. https://doi. org/10.1007/978-981-10-1953-1_2

90. Nowack B (2008) Pollution prevention and treatment using nanotechnology. In: Krug H (ed) Environmental aspects, vol 2. WILEYVCH Verlag GmbH \& Co. KGaA, Weinheim

91. Nowack B (2008) Pollution prevention and treatment using nanotechnology. Nanotechnology 2:1-15

92. Obaje SO, Omade JI, Dambatta UA (2013) Clays and their industrial applications: synoptic review. Int J Sci Technol 3(5):264-270

93. Ojemaye MO, Okoh OO, Okoh Al (2017) Surface modified magnetic nanoparticles as efficient adsorbents for heavy metal removal from wastewater: progress and prospects. Mater Express. https://doi.org/10.1166/mex.2017.1401

94. Pandey S, Ramontja J (2016) Natural bentonite clay and its composites for dye removal: current state and future potential. Am J Chem Appl 3(2):8-19

95. Pereira FAR, Sousa KS, Cavalcanti GRS, Fonseca MG, de Souza AG, Alves APM (2013) Chitosan-montmorillonite biocomposite as an adsorbent for copper (II) cations from aqueous solutions. Int J Biol Macromol 61:471-478

96. Plappally AK, Yakub I, Brown LC, Soboyejo WO, Soboyejo ABO (2011) Physical properties of porous clay ceramic-ware. J Eng Mater Technol 133:031004-1. http://www.asme.org/terms/ Terms_Use.cfm

97. Pranoto I, Fathoni F (2018) Effectiveness study of drinking water treatment using clays/andisol adsorbent in lariat heavy metal cadmium (Cd) and bacterial pathogens. In: IOP conference series: materials science and engineering, vol 349, pp 012047. https://doi.org/10.1088/1757-899x/349/1/012047

98. Qu X, Alvarez PJJ, Li Q (2013) Applications of nanotechnology in water and wastewater treatment. Water Res 47(12):3931-3946. https://doi.org/10.1016/j.watres.2012.09.058

99. Rakhila Y, Ezzahi A, Elmchaouri A, Mestari A (2018) Synthesis and characterization of a red clay based new composite ceramic material. Adv Mater Phys Chem 8:295-310. http:// www.scirp.org/journal/ampc

100. Rao RAK, Kashifuddin M (2012) Adsorption properties of coriander seed powder (Coriandrum sativum): extraction and preconcentration of $\mathrm{Pb}$ (II), $\mathrm{Cu}$ (II) and $\mathrm{Zn}$ (II) ions from aqueous solution. Adsorpt Sci Technol 30:127-146

101. Rao RAK, Kashifuddin M (2014) Kinetics and isotherm studies of Cd (II) adsorption from aqueous solution utilizing seeds of bottlebrush plant (Callistemon chisholmii). Appl Water Sci 4:371-383

102. Rao RAK, Rehman F, Kashifuddin M (2012) Removal of $\mathrm{Cr}(\mathrm{VI})$ from electroplating wastewater using fruit peel of Leechi (Litchi chinensis). Desalination Water Treat 49:136-146

103. Rao RAK, Ikram S, Uddin MK (2015) Removal of $\mathrm{Cr}(\mathrm{VI})$ from aqueous solution onseeds of Artimisia absinthium (novel plant material). Desalination Water Treat 54:3358-3371 
104. Rytwo G (2012) The use of clay-polymer nanocomposites in wastewater pretreatment. Sci World J 498503:7. https://doi. org/10.1100/2012/498503

105. Sanusi KA, Umar BA, Sani IM (2016) Evaluation of the Application of Carica papaya seed modified feldspar clay for adsorption of $\mathrm{Pb}+2$ and $\mathrm{Cu}+2$ in aqueous media: equilibrium and thermodynamic studies. J Environ Anal Toxicol 6:2. https://doi. org/10.4172/2161-0525.1000351

106. Sari A, Tuzen M (2014) Cd (II) adsorption from aqueous solution by raw and modified kaolinite. Appl Clay Sci 88:63-72

107. Sebastian S, Mayadevi S, Beevi S, Mandal S (2014) Layered clay-alginate composites for the adsorption of anionic dyes: a biocompatible solution for water/wastewater treatment. J Water Res Protect 6:177-184. https://doi.org/10.4236/jwarp .2014 .63023

108. Shao Hua, Pinnavaia Thomas J (2010) Synthesis and properties of nanoparticle forms saponite clay, cancrinite zeolite and phase mixtures thereof. Microporous Mater 133(1-3):10-17. https://doi.org/10.1016/j.micromeso.2010.04.002

109. Sivashankar R, Sathya AB, Vasantharaj K, Sivasubramanian $V$ (2014) Environmental nanotechnology, monitoring and management magnetic composite an environmental super adsorbent for dye sequestration-a review. Environ Nanotechnol Monit Manag 1-2:36-49. https://doi.org/10.1016/j. enmm.2014.06.001

110. Srinivasan R (2011) Advances in application of natural clay and its composites in removal of biological, organic, and inorganic contaminants from drinking water. Adv Mater Sci Eng 2011:17. https://doi.org/10.1155/2011/872531

111. Stathi P, Litina K, Gournis D, Giannopoulos TS, Deligiannakis Y (2007) Physicochemical study of novel organoclays as heavy metal ion adsorbents for environmental remediation. J Colloid Interface Sci 316(2):298-309

112. Tang Q, Tang XW, Li Z, Chen Y, Kuo N, Sun Z (2009) Adsorption and desorption behaviour of $\mathrm{Pb}$ (II) on a natural kaolin: equilibrium, kinetic and thermodynamic studies. J Chem Technol Biotechnol 84(9):1371-1380

113. Theron J, Walker JA, Cloete TE (2008) Nanotechnology and water treatment: applications and emerging opportunities. Crit Rev Microbiol 34:43-69. https://doi.org/10.1080/1040841070 1710442

114. Thomé A, Reddy KR, Reginatto C, Cecchin I (2015) Review of nanotechnology for soil and groundwater remediation: Brazilian perspectives. Water Air Soil Pollut 226(4):121

115. Tirtom VN, Dinçer A, Becerik S, Aydemir T, Çelik A (2012) Comparative adsorption of $\mathrm{Ni}$ (II) and Cd (II) ions on epichlorohydrin crosslinked chitosan-clay composite beads in aqueous solution. Chem Eng J 197:379-386

116. Tjong SC, Wang GS (2004) High-cycle fatigue properties of Albased composites reinforced with in situ $\mathrm{TiB}_{2}$ and $\mathrm{Al}_{2} \mathrm{O}_{3}$ particulates. Mater Sci Eng, A 386(1-2):48-53

117. Tsibranska I, Hristova E (2011) Comparison of different kinetic models for adsorption of heavy metals onto activated carbon from apricot stones. Bul Chem Commun 43(3):370-377

118. Uddin MK (2017) A review on the adsorption of heavy metals by clay minerals, with special focus on the past decade. Chem Eng J 308:438-462

119. Unuabonah El, Taubert A (2014) Clay-polymer nanocomposites (CPNs): adsorbents of the future for water treatment. Appl Clay Sci 99:83-92
120. Unuabonah El, El-Khaiary MI, Olu-Owolabi BI, Adebowale KO (2012) Predicting the dynamics and performance of a polymerclay based composite in a fixed bed system for the removal of lead (II) ion. Chem Eng Res Des 90(8):1105-1115

121. Unuabonah El, Adewuyi A, Kolawole MO, Omorogie MO, Olatunde OC, Fayemi SO, Günter C, Okoli CP, Agunbiade FO, Taubert A (2017) Disinfection of water with new chitosan-modified hybrid clay composite adsorbent. Heliyon 3(8):e00379

122. Unuabonaha El, Ugwujaa CG, Omorogiea MO, Adewale A, Oladoja NA (2018) Clays for efficient disinfection of bacteria in water. Appl Clay Sci 151:211-223. https://doi.org/10.1016/j. clay.2017.10.005

123. Verma MK, Pandey P, De N (2017) Characterization of water retention and release capacity of innovative nano clay polymer composite superabsorbent. J Pharmacogn Phytochem $6(6 \mathrm{~S}): 42-48$

124. Vukovic GD, Marinkovic AD, Skapin SD, Ristic MD, Aleksic R, Peric-Grujic AA et al (2011) Removal of lead from water by amino modified multi-walled carbon nanotubes. Chem Eng J 173(3):855-865

125. Wang $X$ (2012) Nanomaterials as sorbents to remove heavy metal ions in wastewater treatment. J Environ Anal Toxicol. https://doi.org/10.4172/2161-0525.1000154

126. Wang Y, Wei H, Lu Y, Wei S, Wujcik KE, Guo Z (2012) Multifunctional carbon nanostructures for advanced energy storage applications. Nanomaterials 5:755-777. https://doi. org/10.3390/nano5020755

127. Wang H, Tang H, Liu Z, Zhang X, Hao Z, Liu Z (2014) Removal of cobalt (II) ion from aqueous solution by chitosan-montmorilIonite. J Environ Sci 26(9):1879-1884

128. Weaver CE, Pollard LD (1973) Developments in sedimentology, the chemistry of clay minerals, vol 15. Elsevier, Amsterdam, pp $1-213$

129. Wong YWH, Yuen CWM, Leung MYS, Ku SKA, Lam HLI (2006) Selected applications of nanotechnology in textiles. AUTEX Res J 6(1):34-40

130. Wu FC, Tseng RL, Juang RS (2009) Characteristics of elovich equation used for the analysis of adsorption kinetics in dyechitosan systems. Chem Eng J 150(2-3):366-373. https://doi. org/10.1016/j.cej.2009.01.014

131. Zapata (2008) Preparation of nanocomposites by in situ polymerization. J Chilean Chem Soc. http://www.scielo.cl/sciel o.php?pid=S0717

132. Zeng QH, Yu AB, Lu GQ, Paul DR (2005) Clay-based polymer nanocomposites: research and commercial development. J Nanosci Nanotechnol 5(10):00. https://doi.org/10.1166/ jnn.2005.411

133. Zhang D, Sun YFu, Du H (2003) Recent advances of superhero nanocomposite coatings: a review. Surf Coat Technol 167(23):113-119. https://doi.org/10.1016/S0257-8972(02)00903-9

134. Zhang D, Zhou C-H, Lin C-X, Tong D-S, Yu W-H (2010) Synthesis of clay minerals. Appl Clay Sci 50:1-11. https://doi. org/10.1016/j.clay.2010.06.019

135. Zhuang J, Gentry RW (2011) Environmental application and risks of nanotechnology: a balanced view biotechnology and nanotechnology risk assessment: minding and managing the potential threats around us. ACS Symp Ser 3:41-67

Publisher's Note Springer Nature remains neutral with regard to jurisdictional claims in published maps and institutional affiliations. 